\title{
Materiais cerâmicos para células a combustível
}

\section{(Ceramic materials for fuel cells)}

\author{
D. Z. de Florio ${ }^{1,3}$, F. C. Fonseca ${ }^{2}$, E. N. S. Muccillo ${ }^{1,2}$, R. Muccillo ${ }^{1,2}$ \\ ${ }^{1}$ Centro Multidisciplinar para o Desenvolvimento de Materiais Cerâmicos - CMDMC \\ ${ }^{2}$ Centro de Ciência e Tecnologia de Materiais - CCTM \\ Instituto de Pesquisas Energéticas e Nucleares - IPEN \\ Travessa $R$ 400, Cidade Universitária \\ S. Paulo, SP 05508-900 \\ ${ }^{3}$ Instituto de Química, UNESP, R. Prof. Francisco Degni s/n \\ Araraquara, SP 14801-970 \\ dzflorio@ipen.br, cfonseca@ipen.br,enavarro@ipen.br,muccillo@usp.br
}

\begin{abstract}
Resumo
A partir da definição de células a combustível, é feita uma introdução sucinta dos tipos de células e dos materiais cerâmicos que são empregados em projeto e fabricação destes dispositivos geradores de energia elétrica. Tomando por base a ampla literatura científica disponível em publicações periódicas internacionais indexadas e arbitradas, bem como patentes, são relatados com detalhes os materiais cerâmicos com comportamento elétrico adequado para uso como eletrólitos, anodos, catodos, interconectores e selantes, que são os componentes básicos de células a combustível de óxidos sólidos. Por fim, é feita uma avaliação do estado da arte na pesquisa e desenvolvimento de materiais cerâmicos para uso em células a combustível de óxidos sólidos.
\end{abstract}

Palavras-chave: célula a combustível, eletrólito sólido, anodo, catodo, interconector.

\begin{abstract}
Basic definitions of fuel cells and a brief introduction of different types of fuel cells are given. A review of the most important ceramic materials being considered for the design and fabrication of devices for producing electrical energy is presented. Ceramic materials with suitable electrical behavior to be used as electrolytes, anodes, cathodes, interconnectors, and sealants of solid oxide fuel cells are reported with details, taking into account the large number of available indexed and refereed scientific publications and patents. Finally, an evaluation of the state of the art of the research and development of ceramic materials for solid oxide fuel cells is presented.
\end{abstract}

Keywords: fuel cells, solid electrolyte, anode, cathode, interconnector.

\section{INTRODUÇÃO}

Célula a combustível é um dispositivo que converte eletroquimicamente combustíveis químicos em eletricidade; é, essencialmente, uma bateria que não para de fornecer corrente elétrica por causa da contínua alimentação externa de combustível. Em outras palavras, é uma bateria na qual os dois eletrodos não são consumidos durante a descarga, mas agem simplesmente como locais para a reação entre combustível e oxidante [1]. Células a combustível convertem energia química diretamente em energia elétrica com eficiência termodinâmica não limitada pelo ciclo de Carnot [2, 3]. Essa vantagem das células a combustível depende, entretanto, de como os combustíveis que serão utilizados podem ser reformados para produzir hidrogênio e dióxido de carbono [4]. Toda célula a combustível é composta de uma seqüência de unidades, cada uma com quatro componentes: o eletrólito, o eletrodo para o ar (ar é o oxidante), o eletrodo para o combustível (o mais comum é o hidrogênio), e o interconector.

Muitos tipos de células a combustível foram desenvolvidos, sendo as células classificadas geralmente de acordo com o tipo de eletrólito. Os cinco principais tipos são:

1- célula a combustível de ácido fosfórico, operacional a $180{ }^{\circ} \mathrm{C}$;

2- célula a combustível de membrana trocadora de prótons, ou célula a combustível de eletrólito de membrana polimérica, operacional na faixa de temperatura $60-80{ }^{\circ} \mathrm{C}$;

3 - célula a combustível de eletrólito alcalino, operacional a temperaturas relativamente baixas $\left(80^{\circ} \mathrm{C}\right)$. Tem sido usada no ônibus espacial como principal fonte de energia. Embora tenha operado confiável e eficientemente em missões espaciais por mais de 40 anos, não tem sido usada para outras finalidades, principalmente por causa do alto custo [5];

4- célula a combustível de carbonato fundido, operacional 
na temperatura relativamente alta de $650{ }^{\circ} \mathrm{C}$; e

5- célula a combustível de óxido sólido (CCOS, SOFC: Solid Oxide Fuel Cell), operacional com praticamente qualquer combustível por causa da alta temperatura de operação (inicialmente $1000{ }^{\circ} \mathrm{C}$ e, mais recentemente 500-600 ${ }^{\circ} \mathrm{C}$ ) [6].

Na Fig. 1 são mostrados esquematicamente os tipos de célula a combustível.

Neste trabalho serão descritos os principais materiais cerâmicos utilizados e objetos de pesquisa em células a combustíveis de óxidos sólidos: eletrólitos sólidos, catodos, anodos, materiais de interconexão e selantes.

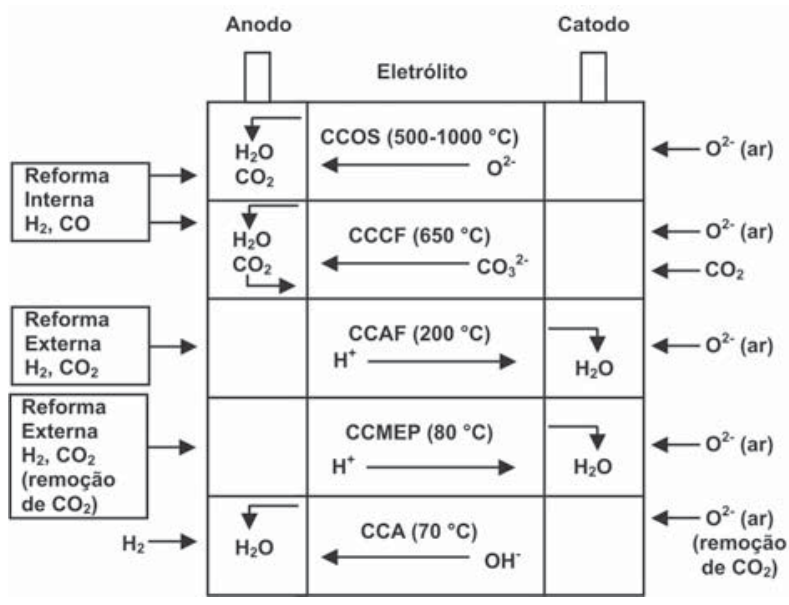

Figura 1: Sumário dos tipos de célula a combustível: A reação de oxidação se dá no anodo (+) e envolve a liberação de elétrons (por exemplo, $\mathrm{O}_{2}+\mathrm{H}_{2} \rightarrow \mathrm{H}_{2} \mathrm{O}+2 \mathrm{e}^{\prime}$ ou $\mathrm{H}_{2} \rightarrow 2 \mathrm{H}^{+}+2 \mathrm{e}^{\prime}$ ). Estes elétrons percorrem o circuito externo produzindo energia elétrica por meio de uma carga externa, e chegam ao catodo (-) para participar do processo de redução (por exemplo, $1 / 2 \mathrm{O}_{2}+2 \mathrm{e}^{\prime} \rightarrow$ $\mathrm{O}^{2-}$ ou $1 / 2 \mathrm{O}_{2}+2 \mathrm{H}^{+}+2 \mathrm{e}^{\prime} \rightarrow \mathrm{H}_{2} \mathrm{O}$ ). Além de produzir energia elétrica e produtos de reação (por exemplo, $\mathrm{H}_{2} \mathrm{O}$ e $\mathrm{CO}_{2}$ ), as reações na célula a combustível também produzem calor. Os produtos de reação são formados no anodo nas células dos tipos CCOS, CCCF e CCEA, e no catodo nas células dos tipos CCAF e CCEMP; CCOS: célula a combustível de óxido sólido; CCCF: célula a combustível de carbonato fundido; CCEA: célula a combustível de eletrólito alcalino; CCAF: célula a combustível de ácido fosfórico; CCAF: célula a combustível de ácido fosfórico; CCEMP: célula a combustível de eletrólito membrana polimérica; e CCA: célula a combustível alcalina.

LFigure 1: Summary of different types of fuel cells: The oxidation reaction in the anode (+) provides electrons (for example, $\mathrm{O}_{2}+\mathrm{H}_{2} \rightarrow \mathrm{H}_{2} \mathrm{O}+2 e^{\prime}$ or $\left.\mathrm{H}_{2} \rightarrow 2 \mathrm{H}^{+}+2 e^{\prime}\right)$. These electrons flow in the external circuit producing electrical energy in an external charge, and reach the cathode (-) for the reduction reaction (for example $1 / 2 \mathrm{O}_{2}+2 e^{\prime} \rightarrow \mathrm{O}^{2-}$ or $1 / 2 \mathrm{O}_{2}+2 \mathrm{H}^{+}+2 e^{\text {' }}$ $\rightarrow \mathrm{H}_{2} \mathrm{O}$ ). One should notice that besides producing electrical energy and reaction products (for example $\mathrm{H}_{2} \mathrm{O}$ and $\mathrm{CO}_{2}$ ), the cell reactions produce also heat. The reaction products are formed in the anode of the SOFC (solid oxide fuel cell), MCFC (molten carbonate fuel cell) and AEFC (alkaline electrolyte fuel cell) types of fuel cells, and at the cathode in the PAFC (phosphoric acid fuel cell) and PEMFC (polymeric-electrolytemembrane fuel cell).]

\section{ELETRÓLITOS SÓLIDOS}

Eletrólitos sólidos são compostos nos quais ocorre condução iônica em uma faixa de temperatura e de pressão parcial dos elementos que os compõem.

Idealmente, um eletrólito sólido é um condutor iônico e um isolante eletrônico. Eletrólitos sólidos são empregados em células eletroquímicas, nas quais os reagentes químicos nos dois eletrodos são gasosos ou líquidos. Eles desempenham três funções críticas: a) separar os reagentes, b) bloquear toda corrente eletrônica para que não flua internamente, sendo forçada a fluir em um circuito externo, e c) promover a condução de portadores de carga iônicos, fornecendo uma corrente iônica interna que deve balancear a corrente eletrônica do circuito externo.

A condutividade elétrica de eletrólitos sólidos para uso em células a combustível deve ser exclusivamente iônica, o portador de carga sendo um íon associado com o oxidante $\left(\mathrm{O}_{2}\right)$ ou com o combustível $\left(\mathrm{H}_{2}\right.$, hidrocarbonetos, etc $)$. Então a escolha se reduz geralmente a eletrólitos sólidos condutores de íons $\mathrm{O}^{2-}$ ou $\mathrm{H}^{+}$. As propriedades que esses materiais devem necessariamente apresentar, fixadas por considerações eletroquímicas e pela alta temperatura de operação, são [7]:

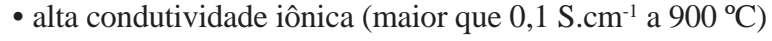

- baixo número de transferência eletrônico $\left(<10^{-3}\right.$ a $\left.900^{\circ} \mathrm{C}\right)$

- estabilidade de fase desde a temperatura ambiente até aproximadamente $1100^{\circ} \mathrm{C}$

- expansão térmica compatível com a dos demais componentes da célula

- compatibilidade química com os materiais de eletrodos e de interconexão, e com o oxigênio e o material combustível

- impermeabilidade a gases

- mecanicamente resistente, com resistência à fratura maior que $400 \mathrm{MPa}$ à temperatura ambiente.

A estes requisitos tecnológicos deve-se somar o requisito econômico, ou seja, os custos dos materiais de partida e de fabricação devem ser moderados.

\section{Eletrólitos Sólidos Condutores de Íons $\mathrm{O}^{2-}$}

Os requisitos acima mostram que para uma cerâmica atuar como eletrólito sólido, deve possuir uma concentração de defeitos iônicos cerca de 1000 vezes superior à de defeitos eletrônicos. Assim, um eletrólito sólido cerâmico é um sólido puro (condutores intrínsecos) com um gap de energia superior a 3 eV ou uma solução sólida onde o número de defeitos iônicos foi aumentado por meio da formação de solução sólida (condutores extrínsecos).

O projeto de células a combustível com eletrólito óxido sólido se baseia no conceito de um eletrólito condutor de íons oxigênio através do qual os íons $\mathrm{O}^{2-}$ migram do catodo (eletrodo do ar) até o anodo (eletrodo do combustível), onde os íons oxigênio reagem com o combustível $\left(\mathrm{H}_{2}, \mathrm{CO}\right.$, etc.) gerando uma tensão (corrente) elétrica.

Segundo J. B. Goodenough, os principais condutores de íons oxigênio conhecidos podem ser classificados quanto às suas estruturas cristalinas [7]: 
1- estrutura fluorita (à base de zircônia, de céria, ou $\left.\delta-\mathrm{Bi}_{2} \mathrm{O}_{3}\right)$;

2- estrutura relacionada à fluorita, como os compostos pirocloro ( $\mathrm{TR}_{2} \mathrm{~B}_{2} \mathrm{O}_{7}$, TR: metal de terra rara, $\mathrm{B}$ : cátion);

3- estrutura de fases do tipo Aurivillius $\left(\mathrm{BMVO}_{\mathrm{x}}, \mathrm{B}\right.$ : cátion, por exemplo $\mathrm{Bi}, \mathrm{M}$ : cátion, por exemplo $\mathrm{Cu}, \mathrm{Ti})$;

4- estrutura relacionada à perovskita, com fórmula geral $\mathrm{ABO}_{3}$ (A, B: cátions), por exemplo titanato de cálcio dopado com alumínio $\left(\mathrm{CaTi}_{1-\mathrm{x}} \mathrm{Al}_{\mathrm{x}} \mathrm{O}_{3-\delta}\right)$ e galato de lantânio dopado com estrôncio e magnésio $\left(\mathrm{La}_{1-\mathrm{x}} \mathrm{Sr}_{\mathrm{x}} \mathrm{Ga}_{1-\mathrm{y}} \mathrm{Mg}_{\mathrm{y}} \mathrm{O}_{3-\delta}\right.$, LSGM).

\section{1- estrutura fluorita}

Em todos os casos, a condução iônica se dá por meio da migração de vacâncias de oxigênio. Dentre estes materiais, aqueles que têm sido mais estudados para fins de utilização em células a combustível de óxido sólido estão: a zircônia estabilizada com ítria (ZEI, na qual a substituição de $\mathrm{Zr}^{4+}$ por $\mathrm{Y}^{3+}$ na faixa $8-10 \mathrm{~mol} \%$ permite manter na temperatura ambiente a fase cúbica, que é estável a altas temperaturas), a céria dopada com gadolínia (cuja principal composição é $\mathrm{Ce}_{0,9} \mathrm{Gd}_{0,1} \mathrm{O}_{1,95}$ ), e o galato de lantânio dopado com estrôncio e magnésio.

As células a combustível de óxido sólido podem, em princípio, operar numa ampla faixa de temperatura, entre $500^{\circ} \mathrm{Ce} 1000^{\circ} \mathrm{C}$; assim, podem ser divididas em dois tipos: operacionais a temperaturas altas $\left(>750{ }^{\circ} \mathrm{C}\right.$, CCOS-TA) e a temperaturas intermediárias (CCOS-TI, de $\sim 500^{\circ} \mathrm{C}$ a $750^{\circ} \mathrm{C}$ ). A aplicação específica da célula, o tipo de combustível, e as propriedades dos eletrólitos sólidos disponíveis determinam a temperatura de operação. Assim, por exemplo, a reforma a vapor de combustíveis fósseis ou derivados de biomassa para a produção de vapores de $\mathrm{H}_{2}$ e $\mathrm{CO}$ para o anodo, requer processadores de combustível operando a temperaturas acima de $700{ }^{\circ} \mathrm{C}$. Desta forma, em última análise, são as propriedades dos eletrólitos sólidos que exercem maior influência no projeto de empilhamentos (necessários para se obter voltagens elevadas) e na seleção de materiais.

A zircônia estabilizada com ítria (8 a $10 \mathrm{~mol} \%$ ) é até o momento o eletrólito sólido favorito para aplicação em CCOSTA. A formação de solução sólida zircônia-ítria tem dupla função: estabiliza a estrutura cristalina cúbica tipo fluorita e forma vacâncias de oxigênio em concentrações proporcionais ao teor de ítria; essas vacâncias são responsáveis pela alta condutividade iônica. A incorporação da ítria na rede cristalina da zircônia pode ser descrita por uma reação de defeitos, utilizando a notação de Kröger e Vink [8]: $\mathrm{Y}_{2} \mathrm{O}_{3} \rightarrow 2 \mathrm{Y}_{\mathrm{Zr}}{ }^{\prime}+3$ $\mathrm{O}_{\mathrm{O}}{ }^{\mathrm{x}}+\mathrm{V}_{\mathrm{O}} \cdot$. Isto significa que para cada mol de dopante $\left(\mathrm{Y}_{2} \mathrm{O}_{3}\right)$ é criada uma vacância de oxigênio duplamente ionizada $\left(\mathrm{V}_{\mathrm{O}}^{*}{ }^{*}\right)$.

A zircônia estabilizada com ítria tem uma condutividade iônica adequada a temperaturas acima de $800^{\circ} \mathrm{C}$, desde que membranas finas (espessura menor que $20 \mu \mathrm{m}$ ) e densas possam ser fabricadas. Essas membranas devem ser livres de impurezas e com apropriada concentração do dopante (entre 8 e $10 \mathrm{~mol} \%$ ). A zircônia estabilizada é quimicamente inerte aos gases reagentes e à maioria dos materiais de eletrodos. A exceção é para catodos que contenham La; nesse caso, há possibilidade de formação da fase $\mathrm{La}_{2} \mathrm{Zr}_{2} \mathrm{O}_{7}$ com estrutura pirocloro na interface entre eletrólito e eletrodo. Esta fase apresenta menor condutividade iônica que a zircônia estabilizada e produz um bloqueio à migração de íons $\mathrm{O}^{2-}$ através da interface. Em termos gerais, a zircônia estabilizada com ítria é o eletrólito sólido mais desenvolvido para a fabricação de células a combustível de alta temperatura, comercialmente viáveis.

A célula a combustível de projeto tubular utiliza como eletrólito sólido a composição contendo $10 \mathrm{~mol} \%$ de $\mathrm{Y}_{2} \mathrm{O}_{3}$,

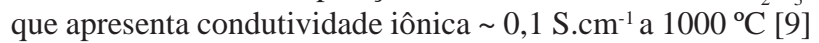
e coeficiente de expansão térmica $\sim 10 \times 10^{-6} \mathrm{~K}^{-1}$ [10]. Para que o desempenho do eletrólito seja otimizado, não deve apresentar porosidade que o torne permeável a gases e deve ser uniformemente fino para minimizar as perdas ôhmicas. Além das propriedades elétricas, a zircônia estabilizada com ítria apresenta propriedades mecânicas adequadas, que foram extensivamente estudadas [11].

A espessura requerida do eletrólito depende da configuração da célula. No modelo planar, por exemplo, o eletrólito de zircônia-ítria com espessura $150 \mu \mathrm{m}$ requer uma temperatura de operação de $950^{\circ} \mathrm{C}$ (Fig. 2). Esta temperatura relativamente alta é um dos principais problemas desta configuração. No modelo tubular, o eletrólito na forma de filme fino $(30$ - $40 \mu \mathrm{m}$ de espessura) é preparado por deposição eletroquímica de vapor sobre o catodo, que é geralmente $\mathrm{La}_{x} \mathrm{Sr}_{1-\mathrm{x}} \mathrm{MnO}_{3-\delta}$ (LSM). O responsável pelo alto custo de fabricação desta configuração de célula é o processo de deposição.

Outras cerâmicas à base de zircônia também apresentam elevados valores de condutividade iônica, como mostrado na Tabela I. Destas soluções sólidas, a zircônia estabilizada com escândia $\left(\mathrm{Sc}_{2} \mathrm{O}_{3}\right)$ tem o valor mais elevado de condutividade iônica, apesar de apresentar envelhecimento térmico acelerado, com conseqüente redução na condutividade iônica a altas temperaturas. $\mathrm{O}$ seu alto valor de condutividade iônica pode contribuir para que este material seja utilizado em temperaturas intermediárias, nas quais não ocorre degradação significativa da condutividade iônica. Os principais fatores limitantes, neste caso, são a pureza e a disponibilidade do óxido de escândio [12].

No caso dos eletrólitos à base de óxido de bismuto, a fase de alta temperatura $\delta-\mathrm{Bi}_{2} \mathrm{O}_{3}$ apresenta os maiores valores de condutividade iônica conhecidos até o momento $\left(2,3 \mathrm{~S} . \mathrm{cm}^{-1} \mathrm{a}\right.$ $\left.800^{\circ} \mathrm{C}\right)$. Entretanto, esta fase é estável num intervalo de temperatura muito pequeno, entre $730{ }^{\circ} \mathrm{C}$ e sua temperatura de fusão a $804{ }^{\circ} \mathrm{C}$. $\mathrm{O}$ composto $\delta-\mathrm{Bi}_{2} \mathrm{O}_{3}$ apresenta estrutura cristalina relacionada à da fluorita, com os íons oxigênio ocupando aleatoriamente $3 / 4$ dos interstícios tetraédricos da sub-rede do $\mathrm{Bi}$, cúbica de face centrada. À temperatura ambiente a fase $\alpha-\mathrm{Bi}_{2} \mathrm{O}_{3}$ apresenta estrutura monoclínica, com vacâncias de oxigênio ordenadas. Durante o aquecimento, ao atingir $730{ }^{\circ} \mathrm{C}$ ocorre uma transição de fase $\alpha \rightarrow \delta$ do tipo ordem-desordem e um aumento de três ordens de grandeza na condutividade iônica. A substituição de Bi por outros cátions, tais como W, Y, ou Gd, promove a estabilização da fase de alta temperatura. Foi demonstrado que as substituições de 22 a $27 \mathrm{~mol} \% \mathrm{WO}_{3}, 25$ a $43 \mathrm{~mol} \% \mathrm{Y}_{2} \mathrm{O}_{3}$ ou 35 a $50 \mathrm{~mol} \% \mathrm{Gd}_{2} \mathrm{O}_{3}$ promovem na temperatura ambiente a estabilização da fase de 
alta temperatura $[14,15,16]$. A substituição parcial de Bi por Y suprime a transição de fase ordem-desordem, apesar de ocorrer uma redução nos valores de condutividade iônica a altas temperaturas. O mesmo efeito acontece com outros cátions, os íons de terras raras. Especialmente, a substituição de Bi por Er permite obter valores de condutividade iônica mais elevados do que a substituição de Bi por Y. Outro problema apresentado por essas cerâmicas é a degradação térmica acelerada a $600^{\circ} \mathrm{C}$ por causa da transformação de fase que dá origem a uma estrutura romboédrica contendo vacâncias ordenadas e, como consequiência, reduz drasticamente a condutividade iônica. A adição de pequenas quantidades de $\mathrm{ZrO}_{2}, \mathrm{ThO}_{2}$ ou $\mathrm{CeO}_{2}$ elimina o efeito de envelhecimento térmico $[17,18]$. Os eletrólitos sólidos à base de $\mathrm{Bi}_{2} \mathrm{O}_{3}$ também apresentam redução na atmosfera do anodo de uma célula a combustível de óxido sólido. De forma geral, o conjunto de problemas com o uso deste tipo de eletrólito sólido tem desestimulado sua aplicação nestas células.

Os altos custos aliados aos requisitos de materiais têm favorecido o desenvolvimento de células a combustíveis que operem a temperaturas intermediárias $\left(<750^{\circ} \mathrm{C}\right)$. Para isto é necessário que o eletrólito sólido apresente condutividade iônica mais elevada que a da zircônia estabilizada. Além da zircônia-escândia e das cerâmicas à base de bismuto, óxidos condutores iônicos à base de céria, principalmente a cériagadolínia (CGO), apresentam condutividade iônica muito superior à da zircônia estabilizada com ítria. As cerâmicas à base de céria, contudo, se tornam condutores mistos no lado do anodo a baixas pressões de oxigênio, resultando em curtocircuito interno da célula. Portanto, ocorre um decréscimo na voltagem de circuito aberto e utilização adicional de combustível e, conseqüentemente, uma diminuição da eficiência do sistema. A $500{ }^{\circ} \mathrm{C}$ a condutividade eletrônica é desprezível e esta talvez seja a temperatura ideal de operação de uma célula a combustível utilizando cerâmicas à base de céria como eletrólito. Os principais dopantes, isto é, aqueles que possibilitam maiores valores de condutividade iônica para a céria, são $\mathrm{Sm}_{2} \mathrm{O}_{3}, \mathrm{Gd}_{2} \mathrm{O}_{3}$ e $\mathrm{Y}_{2} \mathrm{O}_{3}$, nesta ordem.

\section{2- estrutura relacionada à fluorita}

Óxidos mistos com fórmula geral $\mathrm{TR}_{2} \mathrm{~B}_{2} \mathrm{O}_{7}$ apresentam estrutura cristalina do tipo pirocloro, que é estruturalmente similar à fluorita. Esta estrutura cristalina pode ser visualizada como uma fluorita $\left(\mathrm{TR}_{4} \mathrm{O}_{8}\right)$ com $1 / 8$ dos sítios de oxigênio vacantes. Entretanto, contrariamente à estrutura fluorita de mesma estequiometria, na estrutura pirocloro as duas sub-redes (catiônica e aniônica) são ordenadas. Desordem Frenkel intrínseca na sub-rede aniônica coloca alguns átomos de oxigênio em sítios normalmente desocupados. Como consequiência, são geradas vacâncias aniônicas, responsáveis pela condutividade iônica. $\mathrm{O}$ fato da estrutura pirocloro ser derivada de uma estrutura fluorita deficiente de oxigênio sugere que uma transição do tipo ordem-desordem pode conduzir a uma fase desordenada apresentando alta condutividade iônica. A estabilidade do ordenamento catiônico é determinada pela razão $\mathrm{r}_{\mathrm{TR}} / \mathrm{r}_{\mathrm{B}}$ dos raios iônicos dos cátions TR e B. Quanto menor for esta razão, é prevista uma menor temperatura de transição ordem-desordem. A solução sólida $\mathrm{Gd}_{2}\left(\mathrm{Ti}_{1-\mathrm{x}} \mathrm{Zr}_{\mathrm{x}}\right) \mathrm{O}_{6} \mathrm{O}^{\prime}$ com $\mathrm{x}>0$,4 é um condutor iônico que apresenta temperatura de transição ordemdesordem de $1000{ }^{\circ} \mathrm{C}$. Entretanto, o valor da condutividade a esta temperatura $\left(\sim 10^{-2} \mathrm{~S}_{\mathrm{cm}} \mathrm{cm}^{-1}\right)$ não é competitivo com o de outros condutores de íons oxigênio.

\section{3- estrutura de fases do tipo Aurivillius}

A família de condutores iônicos conhecida como BIMEVOX é também derivada da estrutura fluorita do $\mathrm{Bi}_{2} \mathrm{O}_{3}$, onde a composição $\mathrm{Bi}_{4} \mathrm{~V}_{2} \mathrm{O}_{11}$ é o membro final da série de soluções sólidas. Esta composição apresenta duas transições de fase $\alpha \Leftrightarrow \beta$ a $450{ }^{\circ} \mathrm{Ce} \beta \Leftrightarrow \gamma$ a $570^{\circ} \mathrm{C}$. A fase $\gamma$ de alta temperatura apresenta elevada condutividade iônica, e a estratégia utilizada para estabilizar a fase condutora à temperatura ambiente é por meio da substituição parcial do vanádio. Dependendo do tipo e do teor do dopante, são formadas soluções sólidas com estruturas $\alpha, \beta$ e $\gamma / \gamma^{\prime}$ do $\mathrm{Bi}_{4} \mathrm{~V}_{2} \mathrm{O}_{11}$. Valores muito elevados de condutividade

Tabela I - Valores de condutividade iônica e de energia de ativação da zircônia estabilizada com cátions trivalentes [13].

[Table I - Values of ionic conductivity and activation energy of zirconia stabilized with trivalent cations.]

\begin{tabular}{|c|c|c|c|}
\hline Dopante & Teor $(\% \mathrm{~mol})$ & $\begin{array}{c}\text { Condutividade a } 1000{ }^{\circ} \mathrm{C} \\
\left(10^{-2}{\left.\mathrm{~S} . \mathrm{cm}^{-1}\right)}^{-1}\right.\end{array}$ & $\begin{array}{c}\text { Energia de ativação } \\
\left(\mathrm{kJ} \cdot \mathrm{mol}^{-1}\right)^{*}\end{array}$ \\
\hline $\mathrm{Y}_{2} \mathrm{O}_{3}$ & 8 & 10,0 & 96 \\
\hline $\mathrm{Sm}_{2} \mathrm{O}_{3}$ & 10 & 5,8 & 92 \\
\hline $\mathrm{Yb}_{2} \mathrm{O}_{3}$ & 10 & 11,0 & 82 \\
\hline $\mathrm{Sc}_{2} \mathrm{O}_{3}$ & 10 & 25,0 & 62 \\
\hline
\end{tabular}


iônica foram encontrados para o chamado BICUVOX-10 $\left(\sim 10^{-2} \mathrm{~S} \mathrm{~cm}^{-1}\right.$ a $\left.350^{\circ} \mathrm{C}\right)$. Esta composição, $\mathrm{Bi}_{2} \mathrm{~V}_{0,9} \mathrm{Cu}_{0,1} \mathrm{O}_{5,35}$ apresenta o menor teor de cobre no qual a estrutura tetragonal de alta temperatura é obtida à temperatura ambiente. Em temperaturas superiores a $500{ }^{\circ} \mathrm{C}$ o BICUVOX sofre redução em pressões parciais de oxigênio menores que $10^{-2}$ atm, desenvolvendo condutividade eletrônica tipo $n$. Na atmosfera redutora do lado do anodo de uma célula a combustível ocorre redução irreversível com formação de outras fases. Ao ar o BICUVOX tem número de transferência iônico $\approx 1$, já tendo sido demonstrada sua utilização como membrana para separação de oxigênio do ar a $437^{\circ} \mathrm{C}$ com $100 \%$ de eficiência. A utilização prática de cerâmicas do tipo BIMEVOX em aplicações eletroquímicas depara-se com várias dificuldades, principalmente por apresentar alta reatividade química, baixa resistência mecânica e alto coeficiente de expansão térmica [7].

\section{4- estrutura relacionada à perovskita}

Mais recentemente, uma família de condutores com estrutura cúbica perovskita deficiente de oxigênio, com base no galato de lantânio $\left(\mathrm{LaGaO}_{3}\right)$, tem sido apontada como potencial candidato para material de eletrólito sólido em células a combustível de óxido sólido [19]. Nestas cerâmicas, La pode ser parcialmente substituído por $\mathrm{Sr}, \mathrm{Ca}, \mathrm{Ba}, \mathrm{Sm}$ ou $\mathrm{Nd}$, enquanto que Ga pode também ser parcialmente substituído por Mg, In, $\mathrm{Al}$ ou Zn. Composições contendo substituições de Sr por La (entre 10 e 20\%) e Mg pelo Ga (entre 10 e 20\%) apresentam elevada condutividade iônica, tanto em atmosfera oxidante quanto redutora, além de coeficientes de expansão térmica comparáveis aos de outros componentes da célula. $\mathrm{O}$ valor de condutividade iônica mais elevado foi determinado para a composição $\mathrm{La}_{0,8} \mathrm{Sr}_{0,2} \mathrm{Ga}_{0,83} \mathrm{Mg}_{0,17} \mathrm{O}_{3-\delta}$ que a $800^{\circ} \mathrm{C}$ atinge $\sim 0,17$ S.cm ${ }^{-1}$ [20]. O número de transporte iônico é aproximadamente 1 numa ampla faixa de pressão parcial de oxigênio $\left(10^{-20}<\mathrm{pO}_{2}\right.$ $<0,4 \mathrm{~atm})$. Este tipo de perovskita não absorve água e não apresenta problemas de envelhecimento térmico até $140 \mathrm{~h}$ numa temperatura de operação de $750{ }^{\circ} \mathrm{C}$ [19]. Entretanto, estas cerâmicas são instáveis no lado do combustível. Em atmosferas redutoras foi observada a perda de Ga tanto no galato de lantânio puro quanto no dopado. A taxa de perda do Ga é determinada pela difusão de íons Ga através do volume do material e a vaporização do óxido de gálio da superfície externa do material [21]. Com o aumento da deficiência em Ga, são também formadas novas fases na superfície das amostras em tratamentos térmicos em atmosferas redutoras a altas temperaturas [21].

\section{Desenvolvimentos recentes [7]}

Dentre as descobertas mais recentes de materiais cerâmicos condutores de íons oxigênio estão duas famílias conhecidas como: LAMOX e apatitas. A família do LAMOX é derivada da estrutura cristalina cúbica do $\beta-\mathrm{La}_{2} \mathrm{Mo}_{2} \mathrm{O}_{9}$ a temperaturas superiores $\mathrm{a} \sim 580{ }^{\circ} \mathrm{C}$. A transição de fase $\alpha \Leftrightarrow \beta$ resulta em aumento por duas ordens de grandeza, aproximadamente, no valor da condutividade iônica. Novamente, a estratégia adotada para estabilizar a fase de alta temperatura à temperatura ambiente é a substituição parcial tanto do La quanto do Mo. Uma limitação para aplicações práticas desta cerâmica é a redução do Mo, que pode ser diminuída pela substituição parcial do Mo por W. Entretanto, para fins de aplicação como eletrólito sólido em células a combustível, são necessários estudos que demonstrem sua viabilidade.

Óxidos com a estrutura da apatita, tipicamente germanatos e silicatos de composição $\mathrm{La}_{10-\mathrm{x}} \mathrm{Ge}_{6} \mathrm{O}_{26+\mathrm{y}}$ e $\mathrm{La}_{10-\mathrm{x}} \mathrm{Si}_{6} \mathrm{O}_{26+\mathrm{y}}$ apresentam altos valores de condutividade iônica. Pode ser citada como exemplo a composição $\mathrm{La}_{9} \mathrm{SrGe}_{6} \mathrm{O}_{26,5}$ que a $950{ }^{\circ} \mathrm{C}$ apresenta condutividade $0,14 \mathrm{~S} . \mathrm{cm}^{-1}$. A baixas temperaturas, esta composição também apresenta altos valores de condutividade iônica (superiores ao da ZEI). Entretanto, este tipo de cerâmica necessita de altas temperaturas de sinterização e, de forma análoga à família LAMOX, muitos estudos deverão ser feitos antes que possa ser viabilizada sua utilização em células a combustível.

A partir da década de 90 , foram estimulados os projetos de empilhamento de células a combustível de óxido sólido de menor dimensão. A temperatura de operação deveria ser reduzida o máximo possível, sem comprometer a cinética de reações de eletrodo e a resistência interna da célula. O desenvolvimento destes tipos de células a combustível de temperatura intermediária e de menor tamanho ganhou espaço entre diversos fabricantes, inclusive para aplicações em suprimento de energia elétrica para funções auxiliares, como por exemplo, em ar condicionado em veículos automotivos. Há vários exemplos de composições apropriadas para este tipo de células a combustível. Admitindo que o eletrólito sólido não deve contribuir com mais de $0,15 \mathrm{Ohm} . \mathrm{cm}^{2}$ para a resistividade específica total por unidade de área, então para um filme de espessura igual a $15 \mu \mathrm{m}$, a condutividade iônica específica associada deve ser superior a $10^{-2} \mathrm{~S} . \mathrm{cm}^{-1}$. Isto ocorre para a zircônia estabilizada com ítria a $700{ }^{\circ} \mathrm{C}$, enquanto que para a céria-gadolínia a temperatura mínima é $500^{\circ} \mathrm{C}$ (Fig. 2). $\mathrm{O}$ uso de eletrólitos na forma de filmes ainda mais finos deve permitir uma redução adicional na temperatura de operação. Entretanto, até o momento a tecnologia de fabricação de filmes não permite reduzir a espessura do filme impermeável de eletrólito, usando processos tecnológicos que não envolvam altos custos. O uso de um filme espesso de eletrólito requer que este seja suportado por um substrato apropriado. Sendo o substrato o principal componente estrutural nessas células, é necessário otimizar os requisitos quanto à resistência mecânica e permeabilidade a gases. A Fig. 2 mostra os gráficos de Arrhenius da condutividade específica dos principais eletrólitos sólidos cerâmicos usados em CCOS.

Em trabalho recente, algumas propriedades de interesse, tais como resistência mecânica, expansão térmica e resistência ao choque térmico, foram comparadas em células à combustível de configuração tubular [22]. As células usadas nesse teste foram preparadas por extrusão e os eletrólitos sólidos investigados foram $\mathrm{La}_{0,8} \mathrm{Sr}_{0,2} \mathrm{Ga}_{0,83} \mathrm{Mg}_{0,17} \mathrm{O}_{3-\delta}$ (LSGM), $\mathrm{CeO}_{2}: \mathrm{Gd}_{2} \mathrm{O}_{3}(\mathrm{CGO})$ e $\mathrm{ZrO}_{2}: 8 \% \mathrm{~mol} \mathrm{Y}_{2} \mathrm{O}_{3}(\mathrm{ZEI})$. Os resultados mostraram que a célula contendo LSGM apresenta menor módulo de ruptura, a uma mesma temperatura, do que as células contendo CGO ou ZEI. O coeficiente de expansão térmica aumentou na sequiência: ZEI/LSGM/CGO. A célula com ZEI 


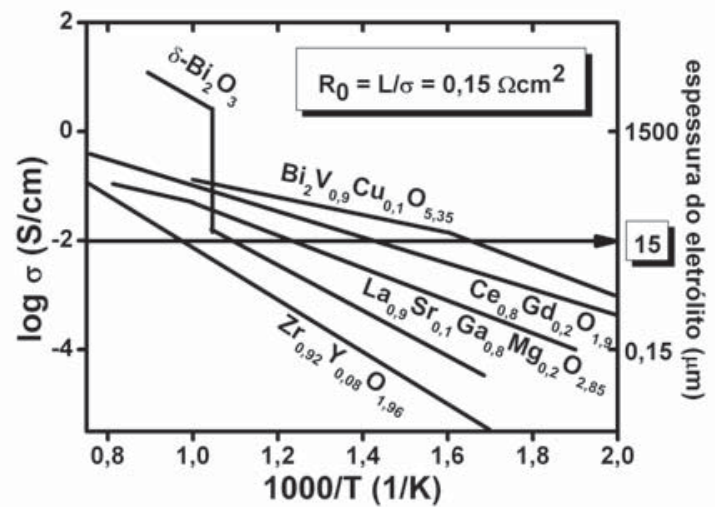

Figura 2: Gráficos de Arrhenius da condutividade específica dos principais tipos de eletrólitos sólidos.

[Figure 2: Arrhenius plots of the specific conductivity of the main kinds of solid electrolytes.]

apresentou maior resistência mecânica à temperatura ambiente, enquanto que a com LSGM, a menor. Com relação à resistência ao choque térmico, todas as células apresentaram bom desempenho, a com ZEI e a com LSGM apresentando o maior e o menor valor, respectivamente.

\section{Eletrólitos Sólidos Condutores de Íons $\mathrm{H}^{+}$}

Recentemente foi proposto que a ciência e a tecnologia da condução de prótons em sólidos devem contribuir no futuro para a economia de energia e para a conservação do meio ambiente [23]. Dispositivos à base de condutores protônicos, consistindo basicamente de uma célula eletroquímica do tipo (eletrodo I / sólido condutor protônico / eletrodo II), são apresentados como promissores para a tecnologia do hidrogênio e a produção de energia limpa.

A condução protônica foi observada em diversos materiais cerâmicos com estrutura cristalina tipo perovskita ou derivadas desta, como a pirocloro. Este tipo de comportamento elétrico foi observado em alguns óxidos, tais como $\mathrm{Cu}_{2} \mathrm{O}, \mathrm{ThO}_{2}, \mathrm{LaYO}_{3}$ e $\mathrm{SrZrO}_{3}$ com condutividade eletrônica parcial. Todos esses óxidos exibem comportamento semicondutor tipo $p$ a altas pressões parciais de oxigênio, como por exemplo ao ar. A condução protônica acontece em óxidos sob atmosfera de hidrogênio devido a buracos h', inicialmente presentes na estrutura cristalina. A reação de equilíbrio pode ser escrita como $\mathrm{H}_{2}(\mathrm{~g})+2 \mathrm{~h}^{\cdot} \rightarrow 2 \mathrm{H}^{+}$.

Numa atmosfera de vapor de água, vacâncias de oxigênio poderiam realizar a mesma função dando origem ao equilíbrio $\mathrm{H}_{2} \mathrm{O}(\mathrm{g})+\mathrm{V}_{\mathrm{O}} \ddot{ } \rightarrow \mathrm{O}_{\mathrm{O}}+2 \mathrm{H}^{+}$.

Recentemente, foi mostrado que cerâmicas com base nos ceratos de estrôncio $\left(\mathrm{SrCeO}_{3}\right)$ e de bário $\left(\mathrm{BaCeO}_{3}\right)$ apresentam condução protônica apreciável a altas temperaturas em atmosferas contendo hidrogênio. Os ceratos não apresentam condução protônica a altas temperaturas, mas condução eletrônica tipo $p$ (buraco) em atmosfera oxidante, desde que não contenha hidrogênio ou vapor d'água. Os materiais investigados apresentam estrutura perovskita e o $\mathrm{Ce}^{4+}$ pode ser parcialmente substituído por cátions trivalentes $\left(\mathrm{Y}^{3+}, \mathrm{Sc}^{3+}\right.$, $\left.\mathrm{Yb}^{3+}\right)$. Estas cerâmicas, quando expostas a hidrogênio ou vapor de água a altas temperaturas, apresentam redução na condutividade eletrônica e o surgimento de condução protônica. Os principais dopantes são aqueles que possuem raios iônicos próximos ao do $\mathrm{Ce}^{4+}\left(\mathrm{r}_{\mathrm{Ce}}=0,97 \AA\right.$ ) [24-26].

Outros condutores protônicos com estrutura tipo perovskita são os óxidos complexos não-estequiométricos do tipo $\mathrm{A}_{2} \mathrm{~B}$ 'B" $\mathrm{O}_{6}$ e $\mathrm{A}_{3} \mathrm{~B}$ 'B” ${ }_{2} \mathrm{O}_{9}$ [27]. Para a composição $\mathrm{A}_{2} \mathrm{~B}$ ' B' $\mathrm{O}_{6}$, $\mathrm{A}, \mathrm{B}$ ' e B" representam cátions divalente $\left(\mathrm{Sr}^{2+}\right.$ ou $\left.\mathrm{Ba}^{2+}\right)$, trivalente e pentavalente, respectivamente. Portanto, a valência média do cátion na posição B é 4+ para a composição estequiométrica. A introdução de vacâncias de oxigênio, por meio de desvio de estequiometria, pode ser obtida simplesmente utilizando um excesso do cátion B' de menor valência em relação ao cátion B" de maior valência. No caso da composição $\mathrm{A}_{3} \mathrm{~B}$ 'B" ${ }_{2} \mathrm{O}_{9}$, o cátion B' é divalente, enquanto que A e B" permanecem com as mesmas valências $(2+$ e 5+, respectivamente). Um exemplo típico desta composição é o condutor $\mathrm{Ba}_{3}\left(\mathrm{Ca}_{1,18} \mathrm{Nb}_{1,82}\right) \mathrm{O}_{9-\mathrm{x}}$ que apresenta valor de condutividade elétrica superior ao do $\mathrm{BaCeO}_{3}$ dopado com $\mathrm{Nd}$, e com comparável valor para a energia de ativação para a migração protônica [28].

Apesar da maior parte dos trabalhos em condutores protônicos se concentrarem em aplicações na engenharia química que requeiram a separação e a geração de hidrogênio, essas cerâmicas continuam sendo bastante estudadas. Foi mostrado recentemente que a composição $\mathrm{BaZr}_{0,9} \mathrm{Y}_{0,1} \mathrm{O}_{2,95}$ apresenta condutividade protônica comparável em valor à condutividade iônica da CGO a $500{ }^{\circ} \mathrm{C}$, ou seja, $10^{-2} \mathrm{~S}_{\mathrm{cm}} \mathrm{cm}^{-1}$ [29, 30]. Resultados de condutividade protônica muito interessantes foram também obtidos para o ácido sólido $\mathrm{CsHSO}_{4}$ a temperaturas de apenas $160{ }^{\circ} \mathrm{C}$ [31].

A existência da condução protônica em óxidos com estrutura pirocloro do tipo $\mathrm{Ln}_{2} \mathrm{Zr}_{2-\mathrm{x}} \mathrm{Y}_{\mathrm{x}} \mathrm{O}_{7-\mathrm{x}}(\mathrm{Ln}=\mathrm{La}, \mathrm{Nd}, \mathrm{Gd}$ e $\mathrm{Sm}$ ) foi identificada há menos de uma década [32]. A substituição parcial do $\mathrm{Zr}^{4+}$ por íons trivalentes aumenta a concentração de vacâncias aniônicas. Esses materiais são condutores protônicos puros em atmosfera de hidrogênio, mas o número de transporte protônico diminui com o aumento da temperatura, devido ao aumento na condutividade eletrônica na presença de vapor de água.

Por causa de suas características, acredita-se que condutores protônicos cerâmicos sejam mais apropriados para aplicações na engenharia química onde a separação e a geração de hidrogênio sejam necessárias [33]. Isto porque para uma célula operando a $600{ }^{\circ} \mathrm{C}$, a densidade de corrente mínima é de $100 \mathrm{~mA} / \mathrm{cm}^{2}$. Estudos recentes [34] mostram a obtenção de metade do valor esperado $\left(50 \mathrm{~mA} / \mathrm{cm}^{2}\right)$ com membranas de $45 \mu \mathrm{m}$ de espessura utilizando o condutor $\mathrm{BaCe}_{0,9} \mathrm{Y}_{0,1} \mathrm{O}_{2,9}$ [34].

\section{CATODOS}

O catodo de uma célula a combustível é a interface entre o ar (ou oxigênio) e o eletrólito; suas principais funções são catalisar a reação de redução do oxigênio e conduzir os elétrons do circuito externo até o sítio da reação de redução. 
Como os demais materiais utilizados em células a combustível de óxido sólido, os catodos devem obedecer alguns critérios gerais:

- baixo custo e facilidade de fabricação

- diferenças mínimas entre os coeficientes de expansão térmica dos diversos componentes da célula

- estabilidade de fase e estabilidade microestrutural durante a operação da célula

- estabilidade química

- compatibilidade com os outros componentes da célula, com os quais mantém contato, durante a sua fabricação e operação

- alta condutividade elétrica mista, iônica e eletrônica

- microestrutura estável mas porosa, durante toda a operação da célula

- alta atividade catalítica para reduzir o oxigênio e ser estável em atmosferas altamente oxidantes [2, 35].

A reação global para a redução do oxigênio no catodo de uma célula a combustível é $\mathrm{O}_{2}+2 \mathrm{~V}_{\mathrm{O}}{ }^{*}+4 \mathrm{e} \rightarrow 2 \mathrm{O}_{\mathrm{O}}{ }^{\mathrm{x}}$ [2]. Essa reação acontece em uma série de processos na superfície e no volume do catodo, bem como na(s) interface(s) catodo/ eletrólito e no contorno de fase tripla (CFT), que é a interface entre os poros do material de eletrodo, preenchidos pelo gás (ar ou oxigênio), o eletrodo e o eletrólito. Um ou mais destes processos podem ser limitantes nas reações catódicas, e eles podem ser, principalmente: a difusão gasosa (externa ao eletrodo ou em seus poros); adsorção ou dissociação do oxigênio na superfície do eletrodo ou eletrólito; difusão do oxigênio adsorvido sobre o eletrodo, sobre o eletrólito até o CFT, ou na interface eletrodo/eletrólito; transferência de carga através da interface eletrodo/eletrólito.

Os materiais, perovskitas do tipo $\mathrm{ABO}_{3}$, mais utilizados como cátodos em células a combustível de óxido sólido são as cerâmicas à base de manganita de lantânio $\left(\mathrm{LaMnO}_{3}\right)$ com substituições dos íons dos sítios A por Sr. Este material preenche a maior parte dos requisitos para sua utilização como catodos de células a combustível cerâmicas operando em temperaturas próximas de $1000^{\circ} \mathrm{C}$. Na estrutura perovskita o cátion do sítio A apresenta coordenação com 12 íons oxigênio e o cátion do sítio B com 6 íons oxigênio. As perovskitas podem ter ambos os sítios A e B substituídos por outros cátions. Cátions com o raio iônico relativamente grande $\left(\mathrm{Sr}^{2+}\right.$, por exemplo) substituem preferencialmente os cátions do sítio A e cátions com o raio relativamente pequeno $(\mathrm{Co}, \mathrm{Fe}, \mathrm{Ni}, \mathrm{Mn}$ e Cr) [35] ocupam os sítios B. A estrutura cristalina é uma função da composição (substituição nos sítios A e B) e estequiometria do oxigênio, a qual é influenciada pela temperatura e pressão parcial de oxigênio. As manganitas de lantânio, com substituição parcial do lantânio por estrôncio são romboédricas à temperatura ambiente, enquanto que a estrutura cristalina do $\mathrm{LaMnO}_{3}$ é ortorrômbica. Entretanto, a transição da estrutura romboédrica para a estrutura tetragonal e até mesmo cúbica pode ocorrer, dependendo das quantidades substituídas nos sítios A e da temperatura (quanto maior a concentração de Sr, menor a temperatura de transição) [36].

As manganitas de lantânio são semicondutores intrínsecos do tipo $p$ e sua condutividade elétrica pode ser aumentada pela dopagem tanto dos sítios A quanto dos sítios B [2]. As propriedades elétricas dos compostos $\mathrm{La}_{\mathrm{x}} \mathrm{Sr}_{1-\mathrm{x}} \mathrm{MnO}_{3-\delta}$ (LSM) são determinadas pela estrutura cristalina e pela composição química [36, 37, 38]. Em geral, as propriedades desses materiais variam com a composição. No entanto, nenhuma cerâmica do tipo LSM foi encontrada, até agora, tal que preencha todos os requisitos de condutividade iônica e eletrônica, compatibilidade dos coeficientes de expansão térmica do catodo e do eletrólito, e estabilidade química nas condições de trabalho de uma célula a combustível de óxido sólido [39]. Isso ocorre devido a vários fatores, como a geometria da célula [40] e as mudanças causadas nos eletrodos devido as condições de operação da célula [39]. Basicamente, a substituição nos sítios A e/ou B modifica várias propriedades dos LSM simultaneamente e nem todas essas modificações são benéficas para o desempenho do catodo. Por exemplo, o aumento da quantidade de $\mathrm{Sr}$ nos sítios A aumenta a condutividade eletrônica devido a uma mudança na razão $\mathrm{Mn}^{3+} / \mathrm{Mn}^{4+}[37,38]$. Nos compostos LSM o máximo de condutividade ocorre na composição $\mathrm{La}_{0,45} \mathrm{Sr}_{0,55} \mathrm{MnO}_{3-\delta}$ (dependendo da temperatura e da pressão parcial de oxigênio, esses valores podem variar, já que estes parâmetros influenciam a estequiometria do oxigênio e a razão $\mathrm{Mn}^{3+} / \mathrm{Mn}^{4+}$.). No entanto, um aumento na quantidade de dopantes nos sítios A provoca um aumento no coeficiente de expansão térmica (Tabela II) [41], incompatibilizando seu uso com os eletrólitos normalmente utilizados em célula a combustível de óxido sólido.

Já a dopagem, ou mesmo a substituição de Mn por Co ou Fe nos sítios B, aumenta a condutividade elétrica; porém, esse aumento na condutividade elétrica é também acompanhado pelo aumento do valor do coeficiente de expansão térmica [42]. Por exemplo, o coeficiente de expansão térmica do $\mathrm{La}_{0,8} \mathrm{Sr}_{0,2} \mathrm{Mn}_{1-\mathrm{y}} \mathrm{Co}_{\mathrm{y}} \mathrm{O}_{3-\delta}$ aumenta monotonicamente com o aumento da quantidade de Co e é maior que $19 \times 10^{-6} \mathrm{~K}^{-1}$ para o composto $\mathrm{La}_{0,8} \mathrm{Sr}_{0,2} \mathrm{CoO}_{3-\delta}$ [42]. Esse alto valor de coeficiente de expansão térmica inviabiliza a utilização dessa composição em célula a combustível de óxido sólido, devido a grande diferença em relação ao coeficiente de expansão térmica da zircônia-ítria (material geralmente usado como eletrólito).

A condutividade iônica dos materiais à base de $\mathrm{LaMnO}_{3}$ é significativamente menor do que a condutividade iônica dos eletrólitos de zircônia-ítria, porém a condutividade iônica aumenta significativamente pela substituição do Mn por Co (Tabela II). Os coeficientes de difusão dos íons oxigênio nas cobaltitas de lantânio podem chegar a ser de 4 a 6 ordens de grandeza maiores quando comparados com os das manganitas de lantânio com dopagens similares. Por exemplo, os valores de condutividade iônica a $900{ }^{\circ} \mathrm{C}$ do $\mathrm{La}_{0,6} \mathrm{Sr}_{0,4} \mathrm{CoO}_{3-\delta}$ e do $\mathrm{La}_{0,65} \mathrm{Sr}_{0,35} \mathrm{MnO}_{3-\delta}$ são, respectivamente, $0,8 \mathrm{~S} . \mathrm{cm}^{-1}$ e $10^{-7} \mathrm{~S} . \mathrm{cm}^{-1}$ [43].

Os materiais à base de $\mathrm{LaMnO}_{3}$ são estáveis em atmosferas oxidantes, requisito para sua utilização como catodo de célula a combustível de óxido sólido na temperatura de operação normal da célula $\left(950-1000{ }^{\circ} \mathrm{C}\right)$. No entanto, esses materiais se decompõem em $\mathrm{La}_{2} \mathrm{O}_{3}$ e $\mathrm{MnO}$ no lado do anodo ou em atmosferas redutoras (em pressões parciais de oxigênio abaixo de $10^{-13}-10^{-14}$ atm na temperatura de $1000{ }^{\circ} \mathrm{C}$ ) [44]. Essa decomposição é reversível e dependente da temperatura e da composição do LSM. A condutividade eletrônica do LSM é 
aproximadamente constante até pressões parciais de oxigênio de $10^{-10}$ atm na temperatura de $1000{ }^{\circ} \mathrm{C}$, mas diminui rapidamente abaixo dessa pressão [36].

Em termos de estabilidade do catodo em relação aos outros componentes da célula, o LSM pode ser considerado estável quando em contato com um eletrólito de zircônia-ítria na temperatura de trabalho de uma célula a combustível; no entanto, para temperaturas maiores que $1250-1350{ }^{\circ} \mathrm{C}$, conforme mencionado anteriormente, é formada uma camada intermediária da fase pirocloro $\mathrm{La}_{2} \mathrm{Zr}_{2} \mathrm{O}_{7}$ e/ou $\mathrm{SrZrO}_{3}$ [45]. Em geral, nos LSM a substituição de pequenas quantidades de $\mathrm{Sr}$ nos sítios A aumenta a estabilidade com relação aos eletrólitos de zircônia-ítria (menor tendência de formação de $\mathrm{La}_{2} \mathrm{Zr}_{2} \mathrm{O}_{7}$ ). À medida que aumenta a razão entre as quantidades dos elementos Sr e La, ocorre uma tendência de formação da fase $\mathrm{SrZrO}_{3}$ [35]. A condutividade de ambas as fases $\mathrm{La}_{2} \mathrm{Zr}_{2} \mathrm{O}_{7}$ e $\mathrm{SrZrO}_{3}$ é várias ordens de grandeza menor que a condutividade do eletrodo e do eletrólito, e dessa forma essas fases bloqueiam o transporte de íons oxigênio nessas interfaces, contribuindo para o aumento da resistividade do sistema [46]. A nãoestequiometria dos sítios A no LSM também influencia a estabilidade do material. O composto LSM preparado com um pequeno excesso de La nos sítios A favorece a formação da fase pirocloro. Além disso, o excesso de La também provoca instabilidade no material durante a sua armazenagem à temperatura ambiente, visto que o $\mathrm{La}_{2} \mathrm{O}_{3}$ é higroscópico, levando à formação de hidróxido de lantânio, o qual reage facilmente com o $\mathrm{CO}_{2}$ da atmosfera formando carbonato de lantânio. Além disso, o excesso de La no material dificulta a adesão entre o eletrodo e o eletrólito. A partir de cálculos termodinâmicos [47], foi determinado que uma deficiência de 10 - 15\% de La nos sítios A aumenta a estabilidade do LSM em relação a zircônia estabilizada. Estes cálculos foram confirmados por observações experimentais [47]. No entanto, à medida que a deficiência de La aumenta nos sítios $\mathrm{A}$, a atividade do $\mathrm{Mn}$ aumenta nos sítios $\mathrm{B}$. A precipitação do $\mathrm{MnO}_{\mathrm{x}}$ é possível se a deficiência nos sítios A for maior que $10 \%$. Uma discussão sobre a dissolução do Mn na zircônia estabilizada, nessas circunstâncias, pode ser encontrada em [48]. Neste estudo foi observado que, apesar da baixa solubilidade do $\mathrm{Mn}^{3+}$ e $\mathrm{Mn}^{4+}$ na zircônia estabilizada, ao ar ou sob atmosfera de oxigênio puro, ocorre a difusão do manganês nos contornos de grão da zircônia estabilizada quando este sistema é tratado à temperatura de $1200{ }^{\circ} \mathrm{C}$ [35]. A 1200 $1250{ }^{\circ} \mathrm{C}$, uma camada difusiva de 50 - $60 \mu \mathrm{m}$ é formada após exposição ao ar por 50 - $100 \mathrm{~h}$. Esse problema é consideravelmente reduzido a $1000{ }^{\circ} \mathrm{C}$, porém não eliminado.

A substituição do Mn por Co nos sítios B diminui a estabilidade do eletrodo em contato com o eletrólito à base de zircônia. Com o aumento da quantidade de Co no LSM, grandes quantidades das fases $\mathrm{La}_{2} \mathrm{Zr}_{2} \mathrm{O}_{7}$ e $\mathrm{SrZrO}_{3}$ têm sido detectadas a temperaturas maiores que $800{ }^{\circ} \mathrm{C}$ [35]. Analogamente, sabe-se que nas perovskitas de ( $\mathrm{LaSr}) \mathrm{FeO}_{3-\mathrm{x}}$ a substituição do $\mathrm{Fe}$ dos sítios B por $\mathrm{Mn}, \mathrm{Cr}$, Co e Ni aumenta a reatividade da fase perovskita com a zircônia [49]. Deve ser mencionado que a formação da(s) fase(s) pirocloro não ocorre se o La for substituído por cátions de terras raras com raios iônicos menores, como por exemplo $\mathrm{Pr}$, ou se outros materiais, como por exemplo soluções sólidas à base de céria, são usados como eletrólito (Tabela II) [50]. Isso pode ser explicado pelo fato de que os compostos $\mathrm{Pr}_{2} \mathrm{Zr}_{2} \mathrm{O}_{7}$ ou $\mathrm{La}_{2} \mathrm{Ce}_{2} \mathrm{O}_{7}$ são termodinamicamente instáveis na temperatura de operação de células a combustível de óxido sólido.

A natureza do material do eletrodo (composição, estabilidade com relação ao eletrólito, coeficiente de expansão térmica), sua microestrutura e valores de condutividade iônica e eletrônica são os critérios de escolha, que devem ser considerados na preparação de catodos de alto desempenho para células a combustível de óxido sólido. Para catodos como o LSM, que possui baixa solubilidade e taxa de difusão para o oxigênio, o contorno de fase tripla CFT (entre o gás, o eletrodo e o eletrólito) se torna de fundamental importância nas reações catódicas, influenciando o processo global da célula [51]. Para se produzir eletrodos com uma extensa região de CFT, o controle da microestrutura do material é fundamental. Para catodos apresentando altos valores de condutividade de íons oxigênio e cinéticas de superfície rápidas, a extensão do CFT e a porosidade se tornam menos significativas, e a área de contato entre o eletrodo e o eletrólito pode ser melhorada pelo uso de eletrodos relativamente densos. A área de superfície especifica, o tamanho e distribuição de poros, e a adesão à superfície do eletrólito são parâmetros importantes para se obter boas taxas de redução de oxigênio na interface catodo/ eletrólito. No entanto, os pós de partida e o processamento cerâmico dos eletrodos influenciam substancialmente o desempenho final. Os métodos mais comuns de preparação de pós cerâmicos para o uso como eletrodos em células a combustível de óxido sólido são: método dos precursores poliméricos, liofilização (freeze drying), pirólise por nebulização (spray pyrolysis), sol-gel, co-precipitação, e processos de combustão [52]. As principais técnicas de deposição do catodo (eletrodo do ar) compreendem, dependendo do projeto da célula, as técnicas de deposição química/eletroquímica de vapor, deposição por plasma (sputtering), colagem de fita (tapecasting), calandragem de fita (tape calendering), impressão sobre tela (screen printing), recobrimento por imersão (dip coating), recobrimento por nebulização (spray coating), eletroforese e nebulização a úmido (wet spray). [35, 53].

Freqüentemente, os pós cerâmicos do catodo são misturados aos pós cerâmicos do eletrólito para aumentar a adesão e o número de sítios reativos. Os compósitos à base de zircôniaítria/perovskita apresentam uma alta atividade catalítica [54].

A atividade eletroquímica do eletrodo, para a reação de redução do oxigênio na interface eletrodo/eletrólito, pode aumentar pela substituição do Mn dos sítios B da estrutura perovskita por Co ou Fe [35]. Essa substituição, no entanto, pode acarretar problemas de tempo de vida, de compatibilidade química com o eletrólito, e a grande diferença apresentada entre os coeficientes de expansão térmica do eletrodo e do eletrólito. Um grande número de perovskitas com a fórmula geral (TR,A)BO $\mathrm{BO}_{3}$ (TR: terra rara, A: Sr e B: Mn, Co, Fe, ou $\mathrm{Cr}$ ) tem sido investigado como catodos potenciais, principalmente para utilização em células a combustível de óxido sólido de temperatura intermediária (CCOS-TI). No 
Tabela II - Condutividade eletrônica, coeficiente de expansão térmica e reatividade com eletrólitos de zircônia-ítria, de vários catodos de células a combustível de óxido sólido.

(Table II - Electronic conductivity, thermal expansion coefficient and reactivity to zirconia-yttria, of several solid oxide fuel cell cathodes)

\begin{tabular}{|c|c|c|c|c|c|c|}
\hline Composição & $\sigma_{\mathrm{e}}\left(\mathrm{S} . \mathrm{cm}^{-1}\right)^{*}$ & ref. & CET $\left[10^{-6}\left(\mathrm{~K}^{-1}\right)\right]^{* *}$ & ref. & reatividade & ref. \\
\hline $\mathrm{Gd}_{0,5} \mathrm{Sr}_{0,5} \mathrm{CoO}_{3-\delta}$ & - & - & - & - & alta & {$[50]$} \\
\hline $\mathrm{Gd}_{0,8} \mathrm{Sr}_{0,2} \mathrm{CoO}_{3-\delta}$ & - & - & - & - & baixa & {$[50]$} \\
\hline $\mathrm{La}_{0,5} \mathrm{Sr}_{0,5} \mathrm{MnO}_{3-\delta}$ & $300(947)$ & {$[35]$} & - & - & - & - \\
\hline $\mathrm{La}_{0,7} \mathrm{Ca}_{0,3} \mathrm{MnO}_{3-\delta}$ & $115(827)$ & {$[41]$} & $10,4(327-827)$ & {$[41]$} & - & - \\
\hline $\mathrm{La}_{0,7} \mathrm{Sr}_{0,25} \mathrm{FeO}_{3-\delta}$ & - & - & - & - & nenhuma & {$[50]$} \\
\hline $\mathrm{La}_{0,7} \mathrm{Sr}_{0,3} \mathrm{MnO}_{3-\delta}$ & $265(947)$ & {$[35]$} & $12,8(25-1100)$ & {$[35]$} & - & - \\
\hline $\mathrm{La}_{0,85} \mathrm{Sr}_{0,15} \mathrm{MnO}_{3-\delta}$ & 175 (947) & {$[35]$} & - & - & - & - \\
\hline $\mathrm{La}_{0,8} \mathrm{Ca}_{0,2} \mathrm{MnO}_{3-\delta}$ & $115(827)$ & {$[41]$} & $10,6(327-827)$ & [41] & - & - \\
\hline $\mathrm{La}_{0,8} \mathrm{Sr}_{0,2} \mathrm{CoO}_{3-\delta}$ & $1000(1000)$ & {$[42]$} & $19,7(100-900)$ & {$[42]$} & alta & {$[50]$} \\
\hline $\mathrm{La}_{0,8} \mathrm{Sr}_{0,2} \mathrm{Fe}_{0,2} \mathrm{Co}_{0,8} \mathrm{O}_{3-\delta}$ & $890(1000)$ & {$[42]$} & $20,7(100-900)$ & {$[42]$} & - & - \\
\hline $\mathrm{La}_{0,8} \mathrm{Sr}_{0,2} \mathrm{Fe}_{0,4} \mathrm{Co}_{0,6} \mathrm{O}_{3-\delta}$ & $435(1000)$ & {$[42]$} & $20(100-900)$ & {$[42]$} & - & - \\
\hline $\mathrm{La}_{0,8} \mathrm{Sr}_{0,2} \mathrm{Fe}_{0,6} \mathrm{Co}_{0,4} \mathrm{O}_{3-\delta}$ & $305(1000)$ & {$[42]$} & $17,6(100-900)$ & [42] & - & - \\
\hline $\mathrm{La}_{0,8} \mathrm{Sr}_{0,2} \mathrm{Fe}_{0,8} \mathrm{Co}_{0,2} \mathrm{O}_{3-\delta}$ & $150(1000)$ & {$[42]$} & $15,4(100-800)$ & [42] & baixa & {$[50]$} \\
\hline $\mathrm{La}_{0,8} \mathrm{Sr}_{0,2} \mathrm{FeO}_{3-\delta}$ & $80(1000)$ & {$[42]$} & $12,6(300-900)$ & {$[42]$} & nenhuma & {$[50]$} \\
\hline $\mathrm{La}_{0,8} \mathrm{Sr}_{0,2} \mathrm{Mn}_{0,4} \mathrm{Co}_{0,6} \mathrm{O}_{3-\delta}$ & $255(1000)$ & [35] & $17,2(200-800)$ & [35] & - & - \\
\hline $\mathrm{La}_{0,8} \mathrm{Sr}_{0,2} \mathrm{Mn}_{0,6} \mathrm{Co}_{0,4} \mathrm{O}_{3-\delta}$ & $125(1000)$ & [35] & $16,1(200-800)$ & {$[35]$} & - & - \\
\hline $\mathrm{La}_{0,8} \mathrm{Sr}_{0,2} \mathrm{Mn}_{0,8} \mathrm{Co}_{0,2} \mathrm{O}_{3-\delta}$ & $130(1000)$ & {$[35]$} & $13,9(200-800)$ & {$[35]$} & - & - \\
\hline $\mathrm{La}_{0,8} \mathrm{Sr}_{0,2} \mathrm{MnO}_{3-\delta}$ & - & - & $12,4(25-1100)$ & {$[35]$} & baixa & {$[50]$} \\
\hline $\mathrm{La}_{0,94} \mathrm{Sr}_{0,05} \mathrm{MnO}_{3-\delta}$ & - & - & $11,7(25-1100)$ & [2] & - & - \\
\hline $\mathrm{La}_{0,9} \mathrm{Ca}_{0,1} \mathrm{MnO}_{3-\delta}$ & $290(827)$ & [41] & $11(327-827)$ & [41] & - & - \\
\hline $\mathrm{La}_{0,9} \mathrm{Sr}_{0,1} \mathrm{MnO}_{3-\delta}$ & - & - & $12(25-1100)$ & {$[35]$} & - & - \\
\hline $\mathrm{LaMnO}_{3}$ & $115(947)$ & [35] & $11,2(25-1100)$ & {$[35]$} & - & - \\
\hline $\mathrm{Nd}_{0,8} \mathrm{Sr}_{0,2} \mathrm{CoO}_{3-\delta}$ & - & - & - & - & média & [50] \\
\hline $\mathrm{Pr}_{0,8} \mathrm{Sr}_{0,2} \mathrm{CoO}_{3-\delta}$ & - & - & - & - & média & [50] \\
\hline $\mathrm{Sm}_{0,8} \mathrm{Sr}_{0,2} \mathrm{CoO}_{3-\delta}$ & - & - & - & - & média & {$[50]$} \\
\hline $\mathrm{Sr}_{0,9} \mathrm{Ce}_{0,1} \mathrm{CoO}_{3-\delta}$ & - & - & - & - & alta & {$[50]$} \\
\hline $\mathrm{Sr}_{0,9} \mathrm{Ce}_{0,1} \mathrm{FeO}_{3-\delta}$ & - & - & - & - & média & {$[50]$} \\
\hline
\end{tabular}

* O número entre parênteses é a temperatura de medida.

** Os números entre parênteses são a faixa de temperatura.

entanto, os LSM com pequenas substituições nos sítios B ainda são amplamente utilizados como catodos. Nesses materiais, a otimização da microestrutura e da interface com o eletrólito pode levar a um excelente desempenho eletroquímico (baixas perdas por polarização) e funcionalidade na sua aplicação.

\section{ANODOS}

O anodo de uma célula a combustível é a interface entre o combustível e o eletrólito. As principais funções de um anodo são:

- prover sítios para reações eletroquímicas catalíticas de oxidação do gás combustível com os íons provenientes do eletrólito

- permitir a difusão do gás combustível para os sítios reativos da interface eletrodo/eletrólito e a remoção dos produtos secundários

- transportar para o interconector (circuito externo) os elétrons que são gerados $[1,55,56]$.

A reação eletroquímica acontece no contorno de fase tripla 
e, considerando o hidrogênio como combustível, é representada por $\mathrm{H}_{2}+\mathrm{O}^{2-} \rightarrow \mathrm{H}_{2} \mathrm{O}+2 \mathrm{e}^{\prime}$.

Os mecanismos das reações eletroquímicas e a extensão do contorno de fase tripla disponível para estas reações são os principais responsáveis pelos processos de polarização do anodo; entretanto, no atual estágio de desenvolvimento, a perda ohmica associada ao anodo é pequena comparada à queda de voltagem total de uma célula a combustível de óxido sólido $[57,58]$.

O anodo da célula a combustível de óxido sólido está exposto a uma atmosfera redutora que pode conter, por exemplo, $\mathrm{H}_{2}, \mathrm{CO}, \mathrm{CH}_{4}, \mathrm{CO}_{2}$ e $\mathrm{H}_{2} \mathrm{O}$. Dependendo do combustível utilizado, o anodo está sujeito à presença, em diferentes concentrações, de materiais particulados, hidrocarbonetos e compostos de enxofre [57]. A escolha e as propriedades do anodo de uma célula a combustível de óxido sólido estão diretamente relacionadas com o combustível utilizado [1, 59].

O material de anodo deve possuir nas condições de operação da célula a combustível boa estabilidade física e química, compatibilidade química e estrutural com o eletrólito e o interconector, alta condutividade eletrônica e iônica e atividade catalítica para a oxidação do combustível [2, 60]. Um aspecto importante da estabilidade exigida é a manutenção da integridade estrutural em toda a faixa de temperatura a que este componente está sujeito: da temperatura de sinterização durante a fabricação até as condições normais de operação e ciclagens até a temperatura ambiente [2]. A compatibilidade com os demais componentes implica na ausência de interdifusão dos elementos constituintes ou a formação de camadas de produtos de reação que possam interferir na funcionalidade do anodo [1]. Ela também implica em uma compatibilidade de propriedades, como o coeficiente de expansão térmica, para minimizar tensões durante as variações de temperatura na operação da célula a combustível. De maneira geral, o desempenho do anodo é definido por suas propriedades elétricas e eletroquímicas e, portanto, tem uma forte dependência com a sua microestrutura [61]. Desta forma, o controle de parâmetros como composição, tamanho e distribuição de partículas e de poros é muito importante para a otimização do desempenho do material de anodo de uma célula a combustível de óxido sólido [61].

Compósitos cerâmica-metal, tipicamente à base de $\mathrm{Ni}$, têm sido comumente utilizados. Entre eles, o compósito $\mathrm{ZrO}_{2}: 8$ mol\% $\mathrm{Y}_{2} \mathrm{O}_{3}$-Ni (ZEI-Ni) é o material convencional das células a combustível que utilizam há 40 anos a zircônia estabilizada com ítria como eletrólito [62, 2]. O Ni é utilizado porque além do baixo custo possui boas propriedades elétricas, mecânicas e catalíticas [60]. Em termos microestruturais, o compósito deve ter uma dispersão homogênea de partículas finas das fases, especialmente do metal, com alta superfície específica e alta porosidade ( 40 vol\%) [2, 61]. A distribuição de tamanhos e a forma das partículas e dos poros devem ser otimizadas para permitir a permeação do gás combustível e evitar as polarizações por concentração (difusão), e também para maximizar a extensão do contorno de frase tripla. Normalmente, a porosidade do anodo é obtida pela adição de formadores de poros, como grafite e amido de milho, pois apenas a redução do $\mathrm{NiO}$ não garante a porosidade final necessária do compósito [61]. A concentração relativa de Ni deve ser maior que o limite de percolação ( 40 vol\%) para condução eletrônica [2, 63], tornando possível o transporte dos elétrons resultantes da reação eletroquímica para o circuito externo. Neste compósito, a zircônia estabilizada com ítria tem três funções principais: (a) evitar a sinterização das partículas metálicas durante a operação da célula a combustível, garantindo sua dispersão e preservando a distribuição de tamanhos das partículas metálicas na temperatura de operação; (b) contribuir para minimizar a diferença dos coeficientes de expansão térmica do Ni e do eletrólito e (c) fornecer trajetórias condutoras de íons oxigênio para estender a região de contorno de fase tripla [2].

O método empregado na fabricação do anodo depende do projeto do dispositivo. No projeto planar da célula a combustível de óxido sólido há uma tendência para o uso do anodo como suporte, garantindo a estabilidade mecânica para as células unitárias. Esta configuração permite o uso de técnicas relativamente simples e de baixo custo para a conformação da célula unitária, tais como colagem de fita e calandragem de fita [64]. Nestes métodos, uma camada do corpo verde do compósito zircônia estabilizada com ítria-óxido de níquel (ZEI$\mathrm{NiO})$ é usada como substrato para uma camada do eletrólito. Em célula a combustível de óxido sólido planar suportada pelo catodo ou pelo eletrólito, geralmente o anodo é depositado por impressão sobre tela [64]. A camada do compósito ZEI$\mathrm{NiO}$ tem espessuras típicas entre 0,5 e $1 \mathrm{~mm}[56,64]$. No projeto tubular da célula a combustível, ao contrário, o anodo não tem a função de prover a estabilidade mecânica da célula unitária e uma suspensão é depositada sobre o eletrólito [64]. A redução do $\mathrm{NiO}$ pode ser feita na própria célula a combustível em um ciclo de aquecimento em atmosfera redutora antes do funcionamento do dispositivo. De fato, uma das limitações do compósito ZEI-Ni é a baixa tolerância a ciclos de oxidação e redução, que ocasionam uma variação volumétrica. Portanto, a operação de uma célula a combustível de óxido sólido deve ter procedimentos especificados para prevenir a oxidação do compósito [33].

Altas densidades de potência $\left(1,8 \mathrm{MW} / \mathrm{cm}^{2}, \sim 3,5 \mathrm{~mA} / \mathrm{cm}^{2}\right.$ a $0,5 \mathrm{mV}$ ) já foram obtidas para células a combustível de óxido sólido usando o anodo ZEI-Ni a $800{ }^{\circ} \mathrm{C}$ [65]. Este compósito atende satisfatoriamente aos requisitos de desempenho, mas apresenta problemas de degradação para longos tempos de utilização e baixa compatibilidade do coeficiente de expansão térmica com o do eletrólito, devido a alta concentração da fase metálica [66]. Por outro lado, as altas temperaturas de operação da célula a combustível e a alta concentração metálica do compósito tornam desnecessário o uso de metais nobres no anodo [56]. Com o objetivo de tentar melhorar a compatibilidade dos coeficientes de expansão térmica, foram propostas algumas composições alternativas para o anodo. Por exemplo, compósitos porosos de $\mathrm{Al}_{2} \mathrm{O}_{3}-\mathrm{Ni}$ ou $\mathrm{TiO}_{2}$-Ni têm sido usados com uma fina camada interfacial de Ni-ZEI-CeO $\mathrm{Cen}_{2}$ ente o anodo e o eletrólito [59].

Atualmente, grande parte dos esforços da pesquisa de 
materiais de anodo visa a obtenção de materiais para células a combustível de óxido sólido de temperaturas intermediárias (CCOS-TI) e também para a oxidação direta de hidrocarbonetos, que permite, por exemplo, o uso de combustível como o gás natural [1,59]. Os compósitos à base de Ni apresentam problemas relacionados à baixa tolerância ao enxofre e, principalmente, à deposição de carbono na superfície do metal para combustíveis hidrocarbonetos. Esta deposição superficial de carbono leva à formação de camadas de grafite nas partículas de $\mathrm{Ni}$ e resulta na destruição do anodo [56]. Para garantir a reforma completa do combustível, principalmente em temperaturas intermediárias, o cermet ZEINi necessita de excesso de vapor d'água para evitar o depósito de carbono [67]. Esta recirculação de vapor d'água no anodo causa um agravamento no desempenho e também um aumento do custo da célula a combustível [68]. Uma camada de céria:ítria $\left(\mathrm{CeO}_{2}: \mathrm{Y}_{2} \mathrm{O}_{3}\right)$ entre o eletrólito de zircônia estabilizada com ítria e o compósito ZEI-Ni já foi utilizada como catalisadora para a reforma do metano em uma célula a combustível operando a $650{ }^{\circ} \mathrm{C}$; entretanto, a temperatura de operação não deve ser elevada acima de $700^{\circ} \mathrm{C}$ para evitar a deposição de carbono na superfície do Ni [69]. A céria é adicionada para melhorar o desempenho do eletrodo, pois tem uma boa atividade catalítica para a oxidação do combustível, sem promover a formação de carbono.

Vários trabalhos de pesquisa tentam superar as limitações do compósito ZEI-Ni desenvolvendo materiais alternativos para o anodo. Considerando os compósitos, o critério de inatividade para as reações catalíticas que resultam na deposição de carbono na superfície exclui a maior parte dos metais de transição, com exceção de $\mathrm{Cu}, \mathrm{Au}$ e Ag. Já foi relatado, por exemplo, que o problema da deposição de carbono observado nos anodos à base de Ni pode ser evitado utilizando anodos de ZEI-Cu a temperaturas intermediárias $[70,67]$. O cobre tem alta condutividade eletrônica e baixa atividade catalítica para a formação de carbono e por isso é escolhido para substituir o níquel. No entanto, o cobre apresenta algumas limitações como, por exemplo, a baixa atividade catalítica para a oxidação de combustíveis hidrocarbonetos e os baixos pontos de fusão do óxido de cobre e do cobre, que torna mais difícil a produção de compósitos com cobre e limita a operação da célula a combustível em temperaturas intermediárias, respectivamente [56]. Desta forma, é necessária a funcionalização do anodo por meio da fabricação de um compósito no qual a condução eletrônica deve ser garantida pelo cobre, e um material diferente deve promover a atividade catalítica para a oxidação do combustível. Neste anodo, a céria é adicionada como catalisadora para a oxidação do combustível e também por apresentar condutividade mista na sua forma reduzida, que permite a transferência dos íons oxigênio do eletrólito para a superfície catalítica e auxilia os processos de transferência de carga no contorno de fase tripla [56]. Já foi observado que a adição de céria ao compósito ZEI-Cu melhora significativamente o desempenho de uma célula a combustível operando com oxidação direta de hidrocarbonetos [71, 72].

Geralmente materiais compósitos, utilizando o eletrólito cerâmico e um metal, são usados como anodos em diferentes tipos de células a combustível, como as de condutores protônicos e as de condutores iônicos de temperatura intermediária (CCOS-TI). Para as células a combustível de temperatura intermediária que utilizam óxidos à base de cério como eletrólito, os anodos mais adequados são os compósitos céria:samária-níquel (CS-Ni) e céria:gadolínia-níquel (CG-Ni) [57, 59, 73]. CS-Ni e CG-Ni com adições de metais nobres como o $\mathrm{Ru}$ e o $\mathrm{Pd}$, que funcionam como catalisadores para a reforma do combustível, mostraram desempenhos promissores [74]. Recentemente, a oxidação direta de hidrocarbonetos em célula a combustível de temperatura intermediária foi demonstrada em eletrólitos de céria-samária. Nos anodos desta célula foi utilizado $\mathrm{CS}-\mathrm{Cu}$, preparado por meio da impregnação de um sal de cobre na matriz porosa, de maneira similar aos compósitos $\mathrm{ZEI}-\mathrm{CeO}_{2}-\mathrm{Cu}$ [56].

Uma alternativa ao uso de compósitos como anodos de célula a combustível de óxido sólido é o uso de óxidos que apresentam condutividade mista e atividade catalítica para as reações de interesse, e que também atendam às demais exigências necessárias para este componente. Para viabilizar a oxidação direta em célula a combustível de óxido sólido é interessante o uso de óxidos condutores eletrônicos como catalisadores. O oxigênio disponível na superfície destas cerâmicas inibe a deposição de carbono nestes anodos, permitindo oxidação direta e estabilidade em longos períodos [60]; entretanto, são relativamente baixas as densidades de potência obtidas em células que usam estes materiais [56].

Diferentemente dos compósitos, nos quais a otimização do desempenho envolve um controle microestrutural e o uso de aditivos, os anodos óxidos ainda se encontram no estágio de definição de uma composição mais adequada. No estágio atual, condutores mistos à base de céria e perovskitas de metais de transição (como Fe, Mn, Cr e Ti) são potenciais candidatos a materiais de anodo para célula a combustível de óxido sólido. A busca por condutores mistos para anodos destas células é tema de vários estudos; entretanto, até o momento estes materiais não apresentam em atmosferas redutoras valores de condutividade eletrônica suficientes para célula a combustível de alto desempenho $[56,60]$. Os óxidos de metais de transição podem assumir diferentes estados de oxidação que podem induzir o transporte eletrônico e, normalmente, aumentar a atividade catalítica [60]. Algumas composições podem ser salientadas, tais como $\mathrm{Zr}_{1-\mathrm{x}-\mathrm{y}} \mathrm{Ti}_{\mathrm{x}} \mathrm{Y}_{\mathrm{y}} \mathrm{O}_{2}$ [75], $\mathrm{La}_{1-\mathrm{x}} \mathrm{Sr}_{\mathrm{x}} \mathrm{A}_{1-\mathrm{y}} \mathrm{M}_{\mathrm{y}} \mathrm{O}_{3}$ (A: $\mathrm{Cr}$ ou Fe; M: Ru, Cr ou Mn) [68, 76, 77], $\mathrm{Sr}_{1-\mathrm{x}} \mathrm{Y}_{\mathrm{x}} \mathrm{TiO}_{3}$ [78], e $\mathrm{La}_{1-\mathrm{x}} \mathrm{Sr}_{\mathrm{x}} \mathrm{TiO}_{3}[79,80]$. Estes materiais satisfazem os requisitos básicos de compatibilidade química e de valores de coeficiente de expansão térmica com o eletrólito de zircônia estabilizada com ítria. Entretanto, valores de condutividade eletrônica e iônica, e da troca superficial de oxigênio em atmosferas redutoras, ainda não se encontram disponíveis de maneira sistemática na literatura. Recentemente, foi anunciada a obtenção da perovskita $\left(\mathrm{La}_{0.75} \mathrm{Sr}_{0.25}\right)_{0.9} \mathrm{Cr}_{0.5} \mathrm{Mn}_{0.5} \mathrm{O}_{3}$, que tem um desempenho comparável ao compósito ZEI-Ni e é estável nas condições de operação de uma célula a combustível [68]. Este óxido apresenta boa compatibilidade de coeficiente de expansão térmica com a ZEI, boa estabilidade em ciclo de 
oxidação/redução e boa atividade catalítica para a oxidação direta de hidrocarbonetos [68].

Embora já tenham sido desenvolvidos anodos catalíticos para oxidação direta de hidrocarbonetos em célula a combustível de óxido sólido, o desempenho destes anodos ainda não atinge os níveis do compósito ZEI-Ni operando com hidrogênio. Portanto, ainda é necessário melhorar as propriedades catalíticas destes anodos. Existe uma clara necessidade de estudos fundamentais das reações catalíticas que ocorrem nos anodos da célula a combustível de óxido sólido; de fato, nem mesmo a reação de oxidação do hidrogênio nos compósitos ZEI-Ni é totalmente conhecida [1]. Neste sentido, a compreensão dos mecanismos envolvidos nas reações de superfície que ocorrem nos contornos de fase tripla do anodo deverá ser importante para os futuros avanços nesta área. Até o momento não há um único material capaz de suprir todas as exigências deste componente com o mesmo desempenho do compósito ZEI-Ni. Tão importante quanto a definição de uma composição adequada do anodo, a microestrutura deste componente deverá ser controlada e otimizada para dispositivos duráveis e de alto desempenho. Logo, pesquisas visando a otimização (composição e microestrutura), particularmente buscando materiais com altos valores de condutividade eletrônica e estabilidade nas condições de operação por longos intervalos de tempo, são necessárias para o desenvolvimento de anodos mais eficientes e, consequientemente, de células a combustível de óxido sólido de alto desempenho, usando os combustíveis atualmente disponíveis.

\section{INTERCONECTORES E SELANTES}

Além dos componentes da célula unitária (catodo, anodo e eletrólito), os materiais cerâmicos são empregados em outros componentes de uma célula a combustível de óxido sólido. Dois deles são fundamentais nestes dispositivos: os materiais interconectores e os selantes. Estes materiais desempenham funções importantes em uma célula a combustível e têm de atender rígidas especificações. Independente do projeto, é necessário um empilhamento de células unitárias para se obter potências elevadas e, portanto, o contato elétrico entre as células unitárias deve ser feito através de um material interconector. Entre as várias células unitárias de um empilhamento de uma célula a combustível de óxido sólido planar, existem as placas bipolares (interconectores) e os fluxos dos gases combustível e oxidante. Neste projeto é necessária uma selagem estanque ao longo das extremidades de cada célula unitária e entre o empilhamento e os distribuidores de gases.

Entre todos os componentes de uma célula a combustível de óxido sólido, o interconector está sujeito às mais severas condições durante a operação do dispositivo e, portanto, deve atender aos mais rigorosos requisitos entre todos os componente [81]. Nos principais projetos em desenvolvimento de célula a combustível de óxido sólido (planar e tubular), o interconector desempenha três funções:

- criar uma barreira física separando o catodo (eletrodo do ar) da atmosfera redutora do anodo (eletrodo do combustível) e, igualmente, evitar o contato do anodo com a atmosfera oxidante do catodo

- conectar eletricamente o anodo de uma célula unitária ao catodo da célula subseqüente de um empilhamento [57]

- distribuir os fluxos dos gases nas superfícies dos eletrodos [57].

Nas condições de operação da célula a combustível de óxido sólido, o interconector deve ter alta condutividade elétrica, preferencialmente com número de transferência próximo de 1, para o transporte eletrônico. Idealmente, a introdução do interconector em um empilhamento não deve aumentar as perdas por queda ohmica, fazendo com que a densidade de potência do empilhamento seja comparável ao de uma célula unitária. Normalmente, o valor de condutividade

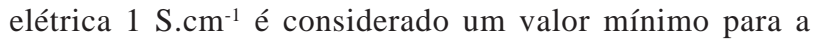
condutividade elétrica deste material, o que corresponde a um valor uma ordem de grandeza maior que o valor da condutividade elétrica da ZEI a $1000{ }^{\circ} \mathrm{C}\left(\sim 0,1 \mathrm{~S} \mathrm{~cm}^{-1}\right)$ [82]. Os interconectores devem ter estabilidades dimensional, química e microestrutural na temperatura de operação da célula a combustível, e também em atmosferas redutoras e oxidantes, uma vez que estão expostos a ambos os gases reagentes. Este material deve manter suas dimensões na presença de um acentuado gradiente de pressão parcial de oxigênio entre as faces em contato com o anodo e com o catodo (seus dois lados), para evitar o desenvolvimento de tensões mecânicas, capazes de resultar em deformações ou mesmo quebra deste componente, que levariam a perdas significativas de desempenho da célula. Nenhum tipo de interdifusão ou reação com os materiais do anodo e do catodo deve ocorrer nas condições de operação para garantir o alto desempenho do empilhamento; portanto, a estabilidade em relação aos materiais adjacentes é crucial no desenvolvimento de materiais interconectores [63]. A microestrutura deste componente não pode também ser modificada pelo gradiente de potencial químico para que não haja variação da condutividade elétrica durante o funcionamento do dispositivo. Outra exigência microestrutural é densificação total e a manutenção desta densidade por longos períodos para garantir a impermeabilidade ao oxigênio e ao hidrogênio, evitando que a combinação direta destas espécies diminua a eficiência da célula [83-85]. O interconector deve possuir valores de coeficiente de expansão térmica compatíveis com os dos eletrodos e do eletrólito, da temperatura ambiente à de operação da célula a combustível, para evitar tensões mecânicas geradas durante os procedimentos de desligamento da celula [2]. Outra propriedade desejável do interconector é que possua alta condutividade térmica. Especialmente no projeto planar operando com reforma interna do combustível, uma alta condutividade térmica permite que o calor gerado no catodo seja conduzido ao anodo facilitando a reação endotérmica de reforma [86]. Os interconectores devem possuir resistência mecânica em altas temperaturas e resistência ao escoamento. Em termos ambientais, é importante que este material não contenha espécies voláteis que possam reagir com eventuais gases contaminadores como $\mathrm{H}_{2} \mathrm{~S}$ e $\mathrm{CO}_{2}$. Também é importante que este material seja de fácil fabricação e, de fato, o desenvolvimento de interconectores funcionais e de baixo custo será vital para a comercialização definitiva de células a 
combustível de óxido sólido [81].

As pesquisas em materiais interconectores têm se concentrado nas últimas décadas em óxidos de terras raras com a estrutura perovskita. Entretanto, poucos óxidos podem satisfazer os rigorosos requisitos deste componente e possíveis materiais são o $\mathrm{YCrO}_{3}$ e o $\mathrm{LaCrO}_{3}$ [81, 63]. A cromita de lantânio é atualmente o material mais adequado para este componente [81]. Esta cerâmica é um semicondutor tipo $p$ e se torna não-estequiométrica pela formação de vacâncias catiônicas [87]. A neutralidade elétrica é mantida pela formação de buracos hं, que compensam as vacâncias catiônicas e são os portadores de carga.

Com o objetivo de otimizar a condutividade elétrica e o coeficiente de expansão térmica, foram feitos diversos tipos de substituições nos sítios catiônicos do $\mathrm{LaCrO}_{3}$. Vários trabalhos mostram os efeitos destas substituições nas propriedades da cromita de lantânio e a sua dependência com a temperatura e a pressão parcial de oxigênio. Os dopantes normalmente empregados são $\mathrm{Mg}$ [88], Ca [89], Sr [90], Ni [91], $\mathrm{Cu}$ [92], $\mathrm{Fe}$ [93] e Co [94]. Ambos os valores de condutividade elétrica e de coeficiente de expansão térmica são significativamente dependentes da natureza do dopante e da pressão parcial de oxigênio. De maneira geral, a condutividade elétrica das cromitas dopadas é consideravelmente menor em atmosferas redutoras e, portanto, um gradiente de condutividade elétrica é estabelecido no interconector durante o funcionamento da célula a combustível de óxido sólido [95]. Coincidentemente, o valor efetivo da condutividade elétrica do $\mathrm{LaCrO}_{3}$ dopado é suficientemente alto para a operação de célula a combustível de óxido sólido a temperaturas maiores que $800{ }^{\circ} \mathrm{C}$ [96]. Entretanto, para temperaturas menores, a condutividade elétrica é substancialmente menor, o que, em princípio, torna inviável a utilização destes materiais em célula a combustível de temperaturas intermediárias [97]. A obtenção de cromitas de lantânio densas também é tema de vários estudos. A densificação ao ar é difícil por causa da volatilidade do $\mathrm{Cr}(\mathrm{VI})$ e a formação de uma camada fina de $\mathrm{Cr}_{2} \mathrm{O}_{3}$ nos pescoços interpartículas no estágio inicial da sinterização [98]. A síntese de pós reativos por meio de diferentes métodos, a sinterização em atmosferas redutoras e posterior tratamento de oxidação, o ajuste de composição para se obter desvios da estequiometria, e a sinterização via fase líquida, têm sido empregados com o objetivo de melhorar a densificação desta cerâmica [99-103].

Com a diminuição da temperatura de operação da célula a combustível de óxido sólido, conseguida por meio da redução da espessura do eletrólito, a substituição desta cerâmica é possível e novos materiais têm sido considerados, como por exemplo, ligas metálicas à base de cromo e aços inoxidáveis ferríticos com recobrimentos de óxidos condutores eletrônicos $\left(\mathrm{Cr}_{2} \mathrm{O}_{3}\right.$, por exemplo) [2, 59] . Entretanto, as ligas desenvolvidas até o momento, apesar de apresentarem certas vantagens em relação aos óxidos, podem ser usadas apenas em células a combustível de óxido sólido operando a temperaturas menores que $700{ }^{\circ} \mathrm{C}$ [81]. Recentemente, foram apresentados avanços nesta área na procura de aços de baixo custo para viabilizar os custos de fabricação de células a combustível [104]. Uma barreira para a implementação de ligas de baixo custo é o forte processo de degradação causado pela vaporização de espécies gasosas contendo cromo no ar úmido da célula. Recobrimentos protetores termicamente compatíveis e de alta condutividade têm sido desenvolvidos com sucesso [104].

Os materiais selantes são responsáveis pela estanqueidade de um empilhamento planar de células unitárias em uma célula a combustível de óxido sólido. Os requisitos que o selante deve obedecer também são extremamente rigorosos. Para evitar a geração de tensões devido a diferenças de expansão térmica, o selante deve ter valor de coeficiente de expansão térmica próximo dos apresentados pelos demais componentes. A compatibilidade química com os demais componentes e com as espécies gasosas dos compartimentos redutores e oxidantes é muito importante. O selante deve ser um bom isolante elétrico para prevenir curto-circuitos em um empilhamento. Os materiais selantes devem ter baixa pressão de vapor e permanecer estanques aos gases durante a vida útil de uma célula a combustível de óxido sólido (> 50.000 h) [63].

Vidros e vitro-cerâmicas têm sido propostos como materiais selantes para célula a combustível de óxido sólido. Estes materiais devem possuir temperatura de transição vítrea mais baixa possível para evitar tensões devidas às diferenças de valores do coeficiente de expansão térmica [105]. Entretanto, a viscosidade destes materiais na temperatura de operação deve ser maior que $10^{3} \mathrm{~Pa}$.s para permanecerem estanques [105]. Os materiais comumente citados são à base de vidros sodacálcia, de outros silicatos alcalinos, de silicatos alcalinos terrosos e de borosilicatos alcalinos [105].

A principal vantagem dos materiais selantes vítreos é que a composição do vidro pode ser controlada para otimizar as propriedades do material. Entretanto, alguns problemas são associados aos vidros como sua natureza frágil e a reatividade com os demais componentes nas condições de operação da célula a combustível de óxido sólido. De fato, as dificuldades associadas à selagem de uma célula a combustível planar despertaram o interesse em projetos circulares deste dispositivo, não sendo neste caso necessário o uso de selantes.

\section{CONSIDERAÇÕES FINAIS}

Materiais cerâmicos têm sido amplamente estudados há várias décadas para utilização em células a combustível, que são dispositivos para a produção de energia elétrica com maior eficiência e sem aparente agressão ao meio ambiente, se comparados com os processos convencionais. Os materiais cerâmicos encontram aplicação tanto como eletrólito quanto como anodo, catodo, interconector e selante, os componentes básicos deste dispositivo. Não tendo sido superados completamente todos os problemas decorrentes da alta temperatura de operação dos primeiros dispositivos desenvolvidos $\left(\sim 1000{ }^{\circ} \mathrm{C}\right)$, continuam os trabalhos de P\&D na busca de materiais compatíveis para operacionalizar dispositivos nesta temperatura, bem como na busca de materiais que permitam a geração de energia elétrica a temperaturas menores. Continua aberto o vasto campo de pesquisa na área de 
materiais cerâmicos com comportamentos elétrico e mecânico para viabilizar a fabricação de dispositivos para a produção de energia limpa a custos competitivos. Neste trabalho, os autores analisam os materiais cerâmicos mais promissores que têm sido estudados recentemente. Ênfase é dada a comunicações em congressos internacionais desta área de pesquisa, nos quais os autores participaram nos últimos anos.

\section{AGRADECIMENTOS}

À Comissão Nacional de Energia Nuclear - CNEN, Fundação de Amparo a Pesquisa do Estado de S. Paulo FAPESP (Procs. 99/10798-0 e 98/14324-0), Conselho Nacional de Desenvolvimento Científico e Tecnológico - CNPq (R.M. 306496/88, E.N.S.M. 300934/94-7), CAPES e PRONEX. D.Z.F. agradece à FAPESP pela bolsa de pósdoutorado (Proc. 03/08793-8).

\section{REFERÊNCIAS}

[1] A. Atkinson, S. Barnett, R. J. Gorte, J. T. S. Irvine, A. J. McEvoy, M. Mogensen, S. C. Singhal, J. Vohs, Nature Mater. 3 (2004) 17.

[2] N.Q. Minh, J. Am. Ceram. Soc. 76 (1993) 563.

[3] K. Kinoshita, E. J. Cairns, Encyclopedia Chem. Technol. 11 (1994) 1098.

[4] W. G. Coors, J. Power Sources 118 (2003) 150.

[5] M. S. Dresselhaus, I. L. Thomas, "Alternative energy technologies", in Nature insight, Materials for clean energy, Nature 414 (15 Nov. 2001) 332.

[6] A. I. Attia, "Battery", in What is Electrochemistry?, Electrochemistry and Solid State Science in the Electrochemical Society, The Electrochemical Society (1997) p. 3.

[7] J. B. Goodenough, Ann. Rev. Mater. Res. 33 (2003) 91.

[8] F. A. Kröger, H. J. Vink, in Solid State Physics, v. 3, eds.: F. Seitz e D. Turnbull, Academic Press, New York (1956) p. 307. [9] D. W. Strickler, W. G. Carlson, J. Am. Ceram. Soc. 47 (1964) 122.

[10] J. Gerretsen, A. Mackor, J. P. G. M. van Eijk, T. P. M. Koster, Proc. $2^{\text {nd }}$ Int. Symp. on Solid Oxide Fuel Cells, Commission of the European Communities, Luxembourg (1991) p. 159.

[11] S. Terauchi, H. Takizawa, T. Endo, S. Uchida, T. Terui, M. Shimada, Mater. Lett. 23 (1995) 273.

[12] J. M. Ralph, A. C. Schoeler, M. Krumpelt, J. Mater. Sci. 36 (2001) 1161.

[13] T. H. Etsell, S. N. Flengas, Chem. Rev. 70 (1970) 339.

[14] T. Takahashi, H. Iwahara, J. Appl. Electrochem. 3 (1973) 65.

[15] T. Takahashi, H. Iwahara, T. Arao, J. Appl. Electrochem. 5 (1975) 187.

[16] T. Takahashi, T. Esaka, H. Iwahara, J. Appl. Electrochem. 5 (1975) 197.

[17] K. Fung, H. D. Back, A. V. Virkar, Solid State Ionics 52 (1992) 199.

[18] K. Huang, M. Feng, J. B. Goodenough, Solid State Ionics 89 (1996) 17.
[19] T. Ishihara, H. Matsuda, Y. Takita, Solid State Ionics 79 (1995) 147.

[20] K. Huang, R. S. Tichy, J. B. Goodenough, J. Am. Ceram. Soc. 81 (1998) 2565.

[21] K. Yamaji, N. Negishi, T. Horita, N. Sakai, H. Yokokawa, $12^{\text {th }}$ Int. Conf. on Solid State Ionics, Halkidiki, Grécia (1999) p. 166.

[22] Y. Du, N. M. Sammes, G. A. Tompsett, D. Zhang, J. Swan, M. Bowden, J. Electrochem. Soc. 150 (2003) 74.

[23] H. Iwahara, Y. Asakura, K. Katahira, M. Tanaka, Solid State Ionics 168 (2004) 299.

[24] H. Iwahara, T. Esaka, H. Uchida, N. Maeda, Solid State Ionics 3-4 (1981) 359.

[25] H. Uchida, N. Maeda, H. Iwahara, J. Appl. Electrochem. 12 (1982) 645.

[26] H. Uchida, N. Maeda, H. Iwahara, Solid State Ionics 11 (1983) 117.

[27] A. Nowick, Y. Du, Solid State Ionics 77 (1995) 137.

[28] N. Imanaka, G.-Y. Adachi, J. Alloys \& Compounds 250 (1997) 492.

[29] K. D. Kreuer, Solid State Ionics 97 (1997) 1.

[30] H. G. Bohn, T. Schober, J. Am. Ceram. Soc. 83 (2000) 768. [31] S. M. Haile, D. A. Boysen, C. R. I. Chisholm, R. B. Merle, Nature 410 (2001) 910.

[32] T. Shimura, M. Komori, H. Iwahara, Solid State Ionics 86-88 (1996) 685.

[33] B. C. H. Steele, A. Heinzel, Nature 414 (2001) 345.

[34] S. Yamaguchi, S. Yamamoto, T. Shishido, M. Omori, A. Okubo, J. Power Sources 129 (2004) 4.

[35] S. P. S Badwal, K. Forger, Mater. Forum 21 (1997) 187.

[36] J. H. Kuo, H. U. Anderson, S. A. Howard, J. Solid State Chem. 87 (1990) 55.

[37] Y. Takeda, S. Nakai, T. Kojima, R. Kanno, N. Imanishi, G. Q. Shen, O. Yamamoto, Mater. Res. Bull. 26 (1991) 153.

[38] J. A. M. van Roosamalen, J. P. P. Huijsmans, L. Plomp, Solid State Ionics 66 (1993) 279.

[39] S. P. Jiang, J. Power Sources 124 (2003) 390.

[40] J. Fleig, Ann. Rev. Mater. Res. 33 (2003) 361.

[41] P. Shuk, L. Tichonova, U. Guth, Solid State Ionics 68 (1994) 177.

[42] L. -W. Tai, M. M. Nasrallah, H. U. Andreson, D. M. Sparlin, S. R. Sehlin, Solid State Ionics 76 (1995) 259.

[43] S. Carter, A. Secuk, R. J. Charter, J. Kajda, J. A. Kilner, B. H. C. Steele, Solid State Ionics 53-56 (1992) 597.

[44] J. H. Kuo, H. U. Anderson, D. M. Sparlin, J. Solid State Chem. 83 (1989) 52.

[45] G. Stochniol, E. Syskakis, A. Naoumidis, J. Am. Ceram. Soc. 78 (1995) 929.

[46] J. A. Labrincha, J. R. Frade, F. M. B. Marques, J. Mater. Sci. 28 (1993) 3809.

[47] H. Yokokawa, N. Sakai, T. Kawada, M. Dokiya, Solid State Ionics 52 (1992) 43.

[48] H. Grübmeier, A. Naoumidis, G. Stochniol, A. Tsoga, Fresenius J. Anal. Chem. 353 (1995) 393.

[49] L. Kindermann, D. Das, H. Nickel, K. Hilpert, Solid State Ionics 89 (1996) 215.

[50] J. M. Ralph, C. Rossignol, R. Kumar, J. Electrochem. Soc. 150 (2003) 1518. 
[51] J. Mizusaki, H. Tagawa, K. Tsuneyoshi, A. Sawata, J. Electrochem. Soc. 138 (1991) 1867.

[52] H. Taguchi, D. Matsuda, M. Nagao, K. Tanihata, Y. Miyamoto, J. Am. Ceram. Soc. 75 (1992) 201.

[53] D. Stöver, P. Buchkremer, F. Tietz, N. H. Menzler, in $5^{\text {th }}$ Eur. Solid Oxide Fuel Cell Forum, Proc. Vol. 1, ed.: J. Huijsmans, Lucerne, Suíça (2002) 1.

[54] M. Mogensen, S. Skaarup, Solid State Ionics 8688 (1996) 1151.

[55] W. Huebner, D. M. Reed, H. U. Anderson, Proc. VI SOFC Int. Symp., eds.: S. C. Singhal, M. Dokiya, Proc. Vol. 99-19, The Electrochemical Society, Inc., USA (1999) 503.

[56] R. J. Gorte, J.M. Vohs, J. Catal. 216 (2003) 477.

[57] Fuel Cell Handbook, $6^{\text {th }}$ Ed., US Department of Energy, Morgantown, WV (2002).

[58] S. M. Haile, Mater. Today 6 (2003) 24

[59] N. P. Brandon, S. Skinner, B. C. H. Steele, Ann. Rev. Mater. Res. 33 (2003) 183

[60] J. T. S. Irvine, D. P. Fagg, J. Labrincha, F. M. B. Marques, Catal. Today 38 (1997) 467.

[61] J.-H. Lee, J.-W. Heo, D.-S. Lee, J. Kim, G.-H. Kim, H.-W. Lee, H. S. Song, J.-H. Moon, Solid State Ionics 158 (2003) 225. [62] H. S. Spacil, "Electrical device including nickel-containing stabilized zirconia electrode", US Patent 3,558,360 (1970).

[63] S. P. S. Badwal, Solid State Ionics 143 (2001) 39.

[64] F. Tietz, H.-P. Buchkremer, D. Stöver, Solid State Ionics 152-153 (2002) 373.

[65] J.-W. Kim, A. V. Virkar, K.-Z. Fung, K. Mehta, S. C. Singhal, J. Electrochem. Soc. 146 (1999) 69.

[66] D. W. Dees, T. D. Claar, T. E. Easler, D. C. Fee, E. C. Mrazek, J. Electrochem. Soc. 134 (1987) 2141.

[67] C. Lu, W. L. Worrell, J. M. Vohs, R. J. Gorte, J. Electrochem. Soc. 150 (2003) 1357.

[68] S. Tao, J. T. S. Irvine, Nature Mater. 2 (2003) 320.

[69] E. P Murray, T. Tsai, S. A. Barnett, Nature 400 (1999) 649.

[70] C. Lu, W. L. Worrell, R. J. Gorte, J. M. Vohs, J. Electrochem. Soc. 150 (2003) 354.

[71] T. Tsai, S. A. Barnett, J. Electrochem. Soc. 145 (1998) 1696. [72] S. Park, J. M. Vohs, R. J. Gorte, Nature 404 (2000) 265.

[73] F. P. F. van Berkel, G. M. Christie, F. H. van Heuveln, J. P. P. Huijsmans, in Proc. $47^{\text {th }}$ Int. Symp Solid Oxid Fuel Cells, eds.: M. Dokiya, O. Yamamoto, H. Takawa, S. C. Singhal, The Electrochemical Society, Pennington, NJ (1995) p. 1062. [74] A. McEvoy, J. Mater. Werkstofftech. 33 (2002) 331.

[75] S. Tao, J. T. S. Irvine, J. Solid State Chem. 165 (2002) 12.

[76] T. Ramos, A. Atkinson, in Ionic and Mixed Conducting Ceramics IV, eds.: T. A. Ramanarayanan, W. L. Worrell, M. Mogensen, Electrochem. Soc. Proc. Vol. PV2001-28 (2001) 352-367.

[77] A.-L. Sauvet, J. Fouletier, J. Power Sources 101 (2001) 259. [78] S. Q. Hui, A. Petric, J. Electrochem. Soc. 149 (2002) 1.

[79] O. A. Marina, L. R. Pederson, in Proc. $5^{\text {th }}$ Eur. Solid Oxide Fuel Cell Forum, Proc. Vol 1, ed.: J. Huijsmans, Lucerne, Suíça (2002) p. 481.

[80] J. Canales-Vázquez, S. W Tao, J. T. S. Irvine, Solid State Ionics 159 (2003) 159.

[81] W. Z. Zhu, S. C. Deevi, Mater. Sci. Eng. A 348 (2003) 227.
[82] N. Q. Minh, C. R. Horne, F. S. Liu, D. M. Moffatt, P. R. Staszak, T. L. Stillwagon, J. J. VanAckeren, Proc. $25^{\text {th }}$ Intersociety Energy Conversion Eng. Conf., vol. 13, Am. Inst. Chem. Eng., New York (1990) p. 256.

[83] C. J. Warde, A. O. Isenberg, J. T. Brown, HighTemperature Solid-Electrolyte Fuel-Cells Status and Programs at Westinghouse, in Program and Abstracts, ERDA/EPRI Fuel Cell Seminar, Palo Alto, CA (June 1976).

[84] S. C. Singhal, in SOFC-VI, Proc. $6^{\text {th }}$ Int. Symp. Solid Oxide Fuel Cells, eds.: S. C. Singhal, M. Dokiya, Honolulu, Hawaii, (October 17/22, 1999) p. 39.

[85] W. J. Dollard, J. T. Brown, Overview Westinghouse Solid Oxide Fuel Cell Program, Fuel Cell Abstracts, Fuel Cell Seminar, Tucson, AZ (Oct. 26/29, 1986).

[86] H. Tsuneizumi, "Development of Solid Oxide Fuel Cell with Metallic Separator", The Int. Fuel Cell Conf. Proc., NEDO/MITI, Tokyo, Japan (1992).

[87] J. Mizusaki, S. Yamauchi, K. Fueki, A. Ishikawa, Solid State Ionics 12 (1984) 119.

[88] H. U. Anderson, R. Murphy, K. Humphrey, B. Rossing, A. Aldred, W. L. Procarioue, R. J. Ackermann, in The Rare Earths in Modern Science and Technology, eds.: G. J. McCarthy, J. J. Rhyne, Plenum Press, New York (1978) p. 55. [89] T. R. Armstrong, J. W. Stevenson, L. R. Pederson, P. E. Raney, J. Electrochem. Soc. 143 (1996) 2919.

[90] T. R. Armstrong, J. W. Stevenson, L. R. Pederson, P. E. Raney, in Proc. $4^{\text {th }}$ Int. Symp. Solid Oxide Fuel Cells, The Electrochem. Soc., eds.: M. Dokiya, O. Yamamoto, H. Tagawa, S. C. Singhal, Pennington, NJ (1995) p. 944.

[91] I. F. Kononyuk, S. P. Tolochko, N. G. Surmach, Neorg. Mater. 22 (1986) 98.

[92] T. R. Armstrong, J. S. Hardy, S. P. Simner, J. W. Stevenson, in SOFC-VI, Proc. $6^{\text {th }}$ Int. Symp. Solid Oxide Fuel Cells, eds.: S.C. Singhal, M. Dokiya, Honolulu, Hawaii (October 17/22, 1999) p. 706.

[93] P. P. Zhuk, A. A. Vecher, V. V. Samokhval, E. N. Naumovich, A. P. Viskup, Neorg. Mater. 24 (1988) 105.

[94] S. P. Tolochko, I. F. Kononyuk, L. S. Ivashkevich, Neorg. Mater. 20 (1980) 1892.

[95] V. H. Schmidt, "Electrical Properties of Lanthanum Chromite Based Ceramics in Hydrogen and Oxidizing Atmospheres of High Temperature", Rept. No. DOE/ET/ 15415-1, US Department of Energy, Washington DC (1981). [96] N. Q. Minh, T. Takahashi, Science and Technology of Ceramic Fuel Cells, Elsevier, Amsterdam (1995).

[97] B. C. H. Steele, in Electrochemistry and Clean Energy, ed.: J. A. G. Drake, Royal Society of Chemistry (1994) p. 8.

[98] H. Yokokawa, N. Sakai, M. Dokiya, J. Electrochem. Soc. 138 (1991) 1018.

[99] B. Krogh, B. Brustad, M. Dahle, J. L. Eilertsen, R. Odegard, in Proc. $5^{\text {th }}$ Int. Symp. Solid Oxide Fuel Cells (SOFCV), Aachen, Germany (1997) p. 1234.

[100] L. A. Chick, J. L. Bates, L. R. Pederson, H. E. Kissinger, in Proc. $1^{\text {st }}$ Int. Symp. Solid Oxide Fuel Cells, ed.: S.C. Singhal, The Electrochem. Soc., Pennington, NJ (1989) p. 170.

[101] N. Sakai, T. Kawada, H. Yokokawa, M. Dokiya, T. Iwata, J. Mater. Sci. 25 (1990) 4531. 
[102] M. Mori, Y. Hiei, N. M. Sammes, Solid State Ionics 123 (1999) 103.

[103] B. K. Klandermeyer, J. T. Dusek, P. E. Blackburn, D. W. Dees, C. C. McPheeters, R. B. Poeppel, Fuel Cell Seminar Abstracts, Tucson, AZ., Courtesy Associates, Washington, DC (1986) p. 68.
[104] C. Lu, T. Sholklapper, C. Jacobson, S. Visco, L. DeJonghe, $5^{\text {th }}$ Int. Symp. Ionic and Mixed Conducting Ceramics (High Temperature Materials), 206 ${ }^{\text {th }}$ Meeting of the Electrochem. Soc., Honolulu, Hawaii (2004) abstr. 1750.

[105] K. L. Ley, M. Krumpelt, R. Kumar, J. H. Meiser, I. Bloom, J. Mater. Res. 11 (1996) 1489.

(Rec. 01/08/04, Rev. 01/10/04, Ac. 24/11/04). 